Article

\title{
Use of Biostimulants: Towards Sustainable Approach to Enhance Durum Wheat Performances
}

\author{
Sourour Ayed ${ }^{1, *,+}$, Imen Bouhaouel ${ }^{2,+}{ }^{\mathbb{D}}$, Hayet Jebari ${ }^{1}$ and Walid Hamada ${ }^{2}$ \\ 1 Field Crops Laboratory, LR20-INRAT-02, National Agricultural Research Institute of Tunisia, \\ University of Carthage, Ariana 2049, Tunisia; hayetjebari99@gmail.com \\ 2 Genetics and Cereal Breeding Laboratory, LR14AGR01, National Agronomic Institute of Tunisia, \\ University of Carthage, Tunis 1082, Tunisia; imenbouhaouel@gmail.com (I.B.); w_hamada@yahoo.com (W.H.) \\ * Correspondence: ayedsourour@yahoo.fr \\ + These authors contributed equally to this work.
}

Citation: Ayed, S.; Bouhaouel, I.; Jebari, H.; Hamada, W. Use of Biostimulants: Towards Sustainable Approach to Enhance Durum Wheat Performances. Plants 2022, 11, 133. https://doi.org/10.3390/ plants11010133

Academic Editor:

Mariateresa Cardarelli

Received: 22 November 2021

Accepted: 17 December 2021

Published: 4 January 2022

Publisher's Note: MDPI stays neutral with regard to jurisdictional claims in published maps and institutional affiliations.

Copyright: (C) 2021 by the authors. Licensee MDPI, Basel, Switzerland. This article is an open access article distributed under the terms and conditions of the Creative Commons Attribution (CC BY) license (https:// creativecommons.org/licenses/by/ $4.0 /)$.

\begin{abstract}
The use of biostimulant (BS) holds a promising and environmental-friendly innovation to address current needs of sustainable agriculture. The aim of the present study is twofold: (i) assess the potential of durum wheat seed coating with microbial BS ('Panoramix', Koppert), a mix of Bacillus spp., Trichoderma spp., and endomycorrhiza, compared to two chemical products ('Spectro' and 'Mycoseeds') through germination bioassay, pot and field trials under semi-arid conditions, and (ii) identify the most effective method of BS supply ('seed coating', 'foliar spray', and 'seed coating + foliar spray') under field conditions. For this purpose, three modern durum wheat cultivars were tested. 'Panoramix' was the most efficient treatment and enhanced all germination (germination rate, and coleoptile and radicle length), physiological (relative water content, chlorophyll content, and leaf area), and agro-morphological (plant height, biomass, seed number per spike, thousand kernel weight, and grain yield) attributes. Unexpectedly, the individual application of 'Panoramix' showed better performance than the combined treatment 'Panoramix + Spectro'. Considering the physiological and agro-morphological traits, the combined method 'seed coating + foliar spray' displayed the best results. Principal component analysis confirmed the superiority of 'Panoramix' treatment or 'seed coating + foliar spray' method. Among tested durum wheat cultivars, 'Salim' performed better especially under 'Panoramix' treatment, but in some case 'Karim' valorized better this BS showing the highest increase rates. Based on these study outcomes, 'Panoramix' might be used as promising sustainable approach to stimulate durum wheat performance.
\end{abstract}

Keywords: Triticum durum; Bacillus spp.; Trichoderma spp.; endomycorrhiza; seed coating; foliar spray; sustainability; semi-arid environment

\section{Introduction}

Various agricultural approaches can be used within an integrated farming system to increase grain yield as well as quality, and alleviate stress-induced limitations. Recently, the use of agricultural biostimulants (BSs) has emerged as a valid alternative to agrochemicals and to indirectly sustain plant growth and productivity [1]. BS was defined as products of biological origin and included many products that are described as metabolic enhancers, phyto-stimulators, biofertilisers, biogenic stimulants, plant growth regulators, plant strengtheners, biocontrol agents, elicitors, allelopathic preparations, and plant conditioners [2]. In general, a plant BS is any natural substance applied to soil/plant that can be classified into several categories: (i) humic substances, (ii) complex organic materials (obtained from agro-industrial and urban waste products, sewage sludge extracts, composts, and manure), (iii) beneficial chemical elements (e.g., aluminium [Al], cobalt [Co], sodium $[\mathrm{Na}]$, selenium [Se], and silicon [Si]), and (iv) inorganic salts including phosphite $\left(\mathrm{HPO}_{3}{ }^{2-}\right)$, seaweed extracts [3]. In addition, plant BS might include beneficial microorganisms such 
as mycorrhizal and non-mycorrhizal fungi, bacterial endosymbionts (e.g., Rhizobium), and plant growth-promoting rhizobacteria (PGPR).

Among microbial BSs, Bacillus and Pseudomonas species are the predominant PGPR widely used as biofertilizers [4]. However, Bacillus-based bio-fertilizers are more active compared to Pseudomonas-based fertilizers [5]. This has been attributed to the production of more effective metabolites and spore forming character of Bacillus spp., which increases the viability of cells in commercially formulated products. The plant-beneficial Bacillus spp. associate with roots or rhizosphere and develop biofilms, allow the assembly of cells embedded in a matrix composed of exopolysaccharides and proteins which indirectly protect plants by inducing systemic resistance and thus increase plant growth and final yield [6].

Some BSs might contain beneficial fungi such as Trichoderma spp., common freeliving fungi in the rhizosphere and soil [7]. Trichoderma spp. is considered as the most important filamentous fungi in biological control strategies [8,9] and an excellent plant growth-promoting fungi (PGPF) $[10,11]$. Trichoderma spp. is present as an active ingredient in more than 200 products worldwide, e.g., biopesticides, biofertilizers, bio-growth enhancers. Moreover, it is marketed for conventional and organic agricultural production [12,13]. Trichoderma-based products are known for their potential to improve plant growth, productivity, nutritional quality as well as resistance to plant pathogens/pests and numerous environmental stresses [8,11,12].

BSs might include also arbuscular mycorrhizal (AM) fungi, the so-called endomycorrhiza, which are obligate symbiotic fungi that predominate roots and rhizosphere [14]. In this symbiotic relationship, the crops supply lipids and/or sugars to their symbionts, thus providing the fungi with a source of carbon for their metabolic needs [15]; in return, the fungi provide benefits to their associated hosts [16]. Several AM fungal species, e.g., Glomus intraradices, Glomus mosseae (renamed to Funneliformis mosseae), Rhizophagus irregularis, and Rhizophagus fasciculatus, have been used to improve crop performance [17].

Currently, some commercial BS products combine the effects of several beneficial microorganisms such as Bacillus spp., Trichoderma spp., and AM fungi that might be applied according to several methods. BSs are usually added to the plant by seed priming, seed coating, foliar spray or root dipping and/or to the soil by direct soil application [17]. Among these methods, seed coating is one of the most promising techniques for delivering beneficial microbes, as it allows small amounts of inocula to be used in a specific application. Inspired from the pharmaceutical industry, seed coating was first applied to cereal seeds in the 1930s, and thereafter, its large-scale commercial use began in the 1960s [18]. Seed coating is the application of exogenous materials onto the surface of seeds in order to improve their appearance and handling characteristics (e.g., seed shape, weight and size). It can also be used to deliver active compounds (e.g., plant growth regulators, micronutrients, and microbial inoculants) that stimulate healthy and rapid establishment, and thereby maximize crop production $[19,20]$. Otherwise, the literature reports several positive effects of BS foliar spray on plant growth, productivity, and quality [21,22]. BS foliar spray is largely used, but this method is expensive and requires large amounts of inoculant [17].

Most of these BS application methods have shown a beneficial effect on crop yield by (i) stimulating germination, vegetative and reproductive growth especially the root development (density and depth), and (ii) improving plant resilience to biotic/abiotic stress after induction of plant biological activity [23-25]. In fact, BSs enhance the crop's physiological and biochemical processes by regulating hormones balance, enhancing photosynthetic activity, nutriment uptake, and nutritional efficiency $[12,13,26]$. Furthermore, BSs could improve the physicochemical properties of soil, the activity of rhizosphere microbes and soil enzymes, and therefore the nutrient bioavailability [1]. Although BSs are beneficial for crop production systems, their modes of action remain largely unknown $[27,28]$. This might be due in part to the great diversity of raw materials (e.g., strain of microorganisms) used in the manufacture of each product, in addition to the diversity related to species or genotypes. In this sense, there is little documented literature on the effects of exogenous 
BSs on durum wheat (Triticum durum Desf.) production. In Tunisia, this species constitutes the largest part of the staple food. However, enhancing sustainable productivity is facing concomitant challenges, especially in semi-arid environment $[29,30]$. In this context, the present study aims to assess (i) the effect of a BS, a microbial consortium of Bacillus spp., Trichoderma spp., and AM fungi, on germination, physiological and agro-morphological attributes under different experimental conditions (Petri dish, pot, and field trials), (ii) the effectiveness of three supply methods of BS under field conditions, and (iii) the genotypic response of three modern durum wheat cultivars to BS treatment and supply methods.

\section{Results}

\subsection{Effects of Seed Coating Treatments on Germination Attributes}

The analysis of variance revealed significant differences ( $p \leq 0.05$ and $p \leq 0.001$ ) among seed coating treatments and cultivars for all germination attributes (Table 1 ). Double interaction 'treatment $\times$ cultivar' was only significant for radicle length $(p \leq 0.05)$. Overall, the results showed that seed coating with BS or chemical products improved germination attributes, except 'Mycoseeds' for germination rate, and 'Spectro' and 'Mycoseeds' for coleoptile length (Table 1, Figure 1). Interestingly, the highest germination rate, coleoptile length, and radicle length were recorded with 'Panoramix' using $2 \mathrm{~mL} \mathrm{~kg}^{-1}$ seeds, inducing respectively an increase rate of 15,11 , and $30 \%$ compared to the control. This treatment was followed by 'Panoramix' using $6 \mathrm{~mL} \mathrm{~kg}^{-1}(13,8$, and $26 \%)$ and $4 \mathrm{~mL} \mathrm{~kg}^{-1}(11,7$, and $26 \%$ ). A differential mode of action of the used products was observed; i.e., 'Panoramix' improved root development more than that of coleoptile, and vice versa for the chemical treatments ('Spectro' and 'Mycosseds').

During this experiment, a genotypic variation was obtained (Table 1, Figure 1). For the seven seed treatments, 'Salim' performed better for the germination rate, while 'Maali' exhibited the best values for the coleoptile length and radicle length. Nonetheless, 'Salim' showed the highest coleoptile length using $2 \mathrm{~mL} \mathrm{~kg}^{-1}$ of 'Panoramix'. It is worth noting that 'Karim' displayed the highest increase rates for the germination rate and coleoptile length using 'Panoramix' $\left(2,4\right.$, and $\left.6 \mathrm{~mL} \mathrm{~kg}^{-1}\right)$, but its values still lower than those of 'Maali' and 'Salim'.

Table 1. Seed coating treatment and cultivar effects on germination attributes. For the three studied variables, the two-way ANOVA is shown according to the different factors.

\begin{tabular}{|c|c|c|c|c|}
\hline Sources of Variation & $\mathrm{df}^{1}$ & GR (\%) & CL $(\mathrm{cm})$ & RL (cm) \\
\hline Treatment (T) & 6 & $5.63 * * * 2$ & $25.13^{* * *}$ & $14.66^{* * *}$ \\
\hline Cultivar (C) & 2 & $3.06 *$ & $3.820 *$ & $5.66^{*}$ \\
\hline $\mathrm{T} \times \mathrm{C}$ interaction & 12 & $1.26^{\mathrm{ns}}$ & $1.69^{\mathrm{ns}}$ & $2.24 *$ \\
\hline \multicolumn{5}{|c|}{ Treatments } \\
\hline Control & & $79.11 b^{3}$ & $6.13 a$ & $8.10 c$ \\
\hline Panoramix $\left(2 \mathrm{~mL} \mathrm{~kg}^{-1}\right)$ & & 93.33a $(15 \%)$ & $6.91 \mathrm{a}(11 \%)$ & $11.64 \mathrm{a}(30 \%)$ \\
\hline Panoramix $\left(4 \mathrm{~mL} \mathrm{~kg}^{-1}\right)$ & & $88.88 \mathrm{ab}(11 \%)$ & $6.59 a(7 \%)$ & $10.92 \mathrm{ab}(26 \%)$ \\
\hline Panoramix $\left(6 \mathrm{~mL} \mathrm{~kg}^{-1}\right)$ & & $91.22 \mathrm{a}(13 \%)$ & $6.67 \mathrm{a}(8 \%)$ & $10.93 \mathrm{ab}(26 \%)$ \\
\hline Spectro & & $81.11 \mathrm{~b}(2 \%)$ & $4.64 \mathrm{~b}(24 \%)$ & $8.76 \mathrm{c}(7 \%)$ \\
\hline Mycoseeds & & $77.89 \mathrm{~b}(-1 \%)$ & $3.97 \mathrm{c}(35 \%)$ & $8.62 c(6 \%)$ \\
\hline $\begin{array}{c}\text { Panoramix }\left(4 \mathrm{~mL} \mathrm{~kg}^{-1}\right)+ \\
\text { Spectro }\end{array}$ & & $79.09 \mathrm{~b}(0.1 \%)$ & $6.76 a(9 \%)$ & $10.06 \mathrm{~b}(19 \%)$ \\
\hline \multicolumn{5}{|c|}{ Cultivars } \\
\hline Karim & & $78.66 \mathrm{~b}$ & $6.20 \mathrm{~b}$ & $9.04 \mathrm{c}$ \\
\hline Maali & & $86.84 a$ & $7.48 \mathrm{a}$ & $12.28 \mathrm{a}$ \\
\hline Salim & & $87.61 \mathrm{a}$ & $7.15 a$ & $11.70 \mathrm{~b}$ \\
\hline
\end{tabular}

${ }^{1} \mathrm{df}$ : freedom degree; GR: germination rate; CL: coleoptile length; RL: radicle length. ${ }^{2}$ ns: non significant; ${ }^{*}$ and ***: significant at $5 \%$ and $0.1 \%$, respectively. ${ }^{3}$ Means with similar letter(s) is not significantly different at $5 \%$ probability level according to Duncan's multiple range test. 

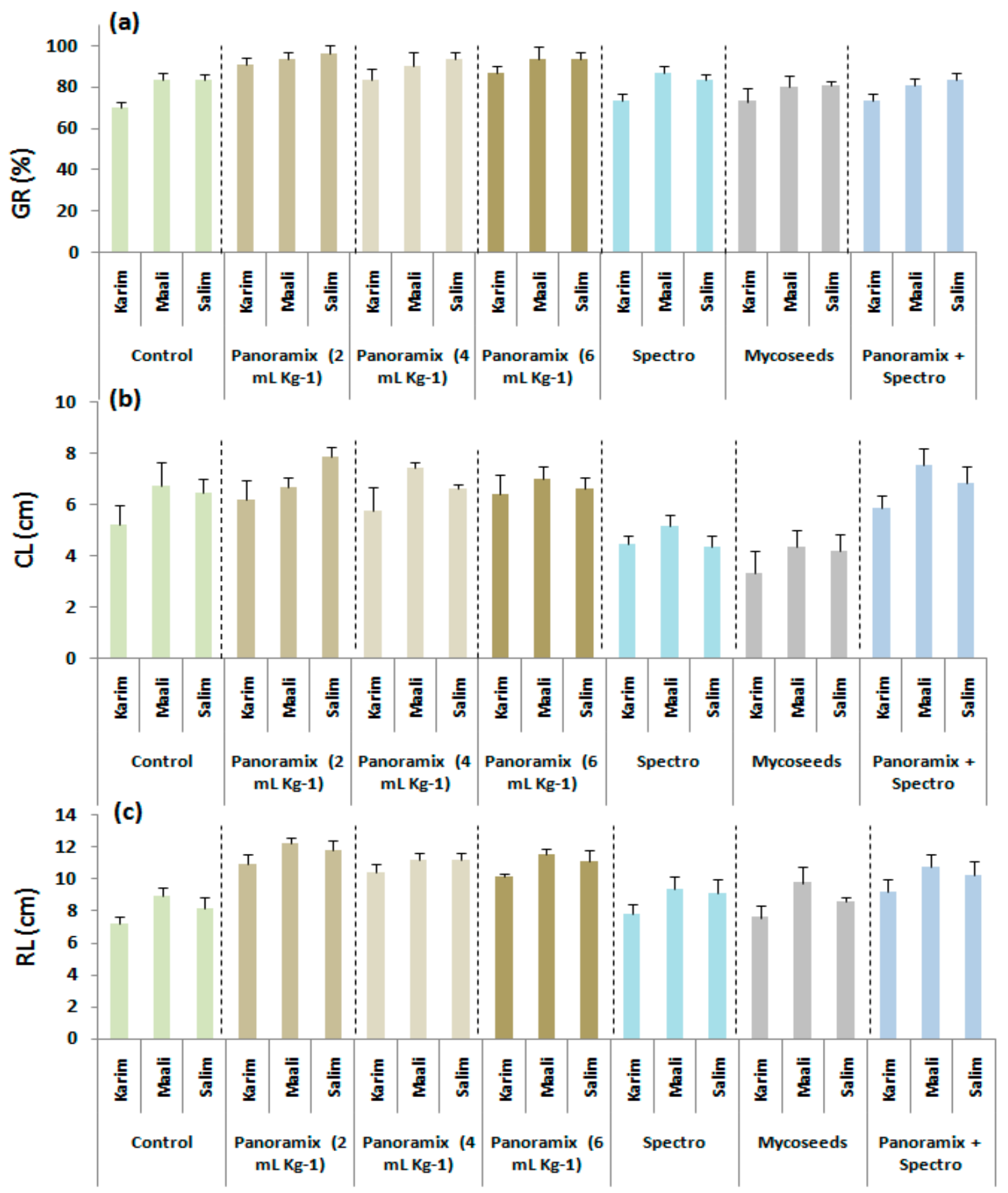

Figure 1. Effects of seed coating treatments on germination rate (GR, a), coleoptile (CL, b), and radicle $(\mathrm{RL}, \mathrm{c})$ length of durum wheat cultivars.

The PCA was applied in order to evaluate the relation between cultivars and applied treatments. The first and the second principal components (PC-1 and PC-2) accounted for 83 and $13 \%$, respectively, of the total data variance; i.e., their mutual projections (Figure 2, Table S1). Three groups might be discerned: the first group combined the chemical treatments ('Spectro' and 'Mycoseeds'), the second group was mainly constituted by all 'Panoramix' treatments, while the last group included the combined treatment, 'Panoramix + Spectro'. The PCA results confirmed the superiority of 'Panoramix' treatment, in particular using the $2 \mathrm{~mL} \mathrm{~kg}^{-1}$ concentration. The BS enhanced mainly the germination rate and radicle length, but its effect depends on the interaction between concentration and cultivar. 
(a)

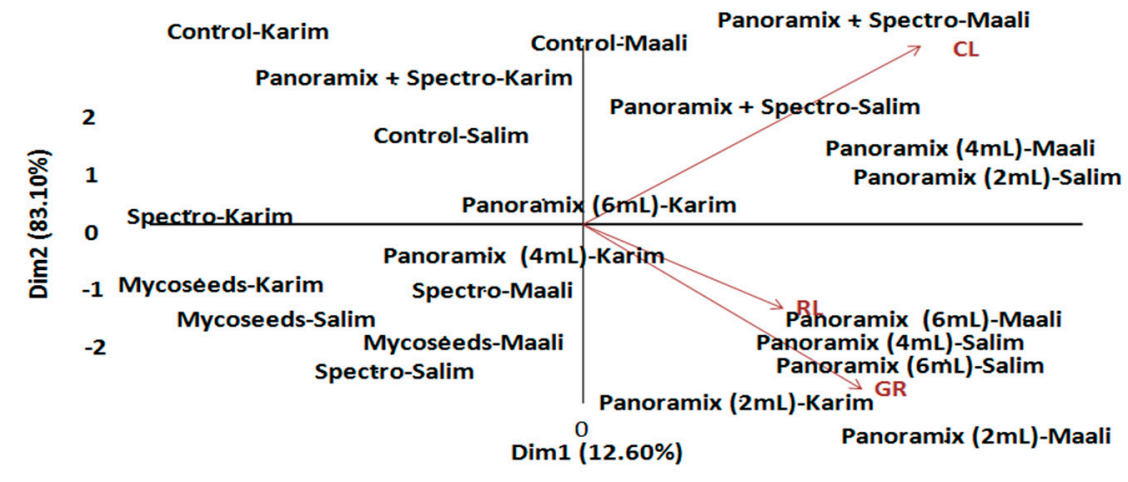

(b)

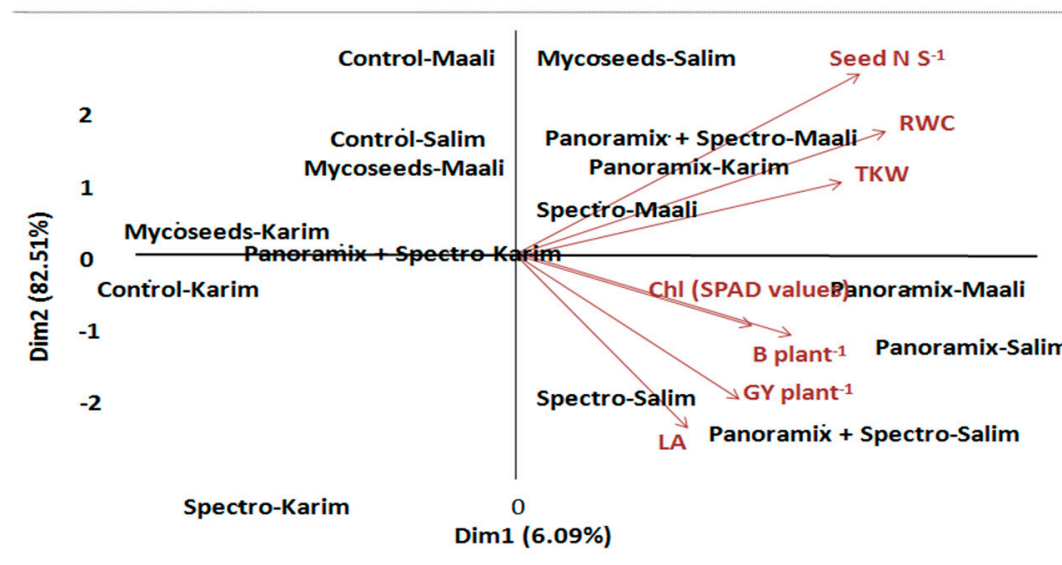

(c)

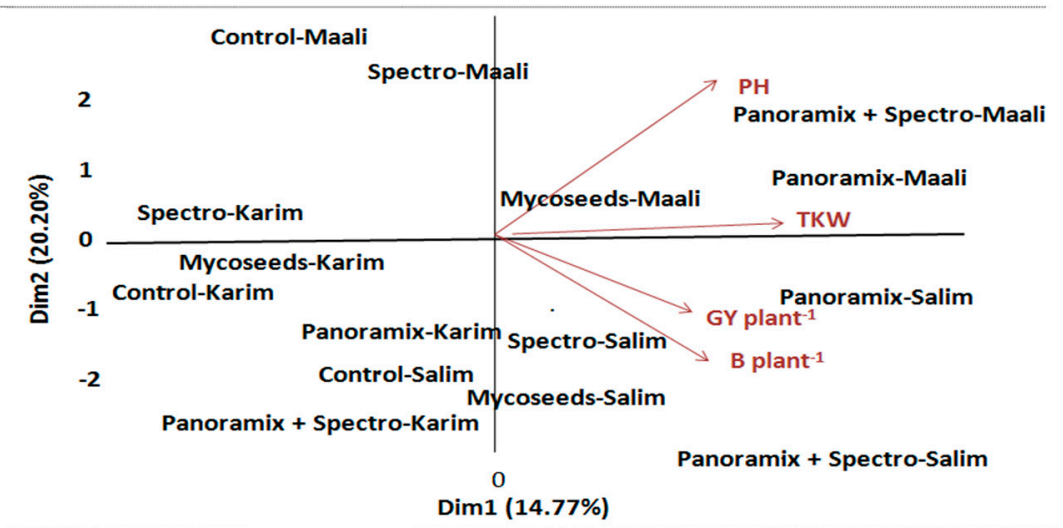

(d)

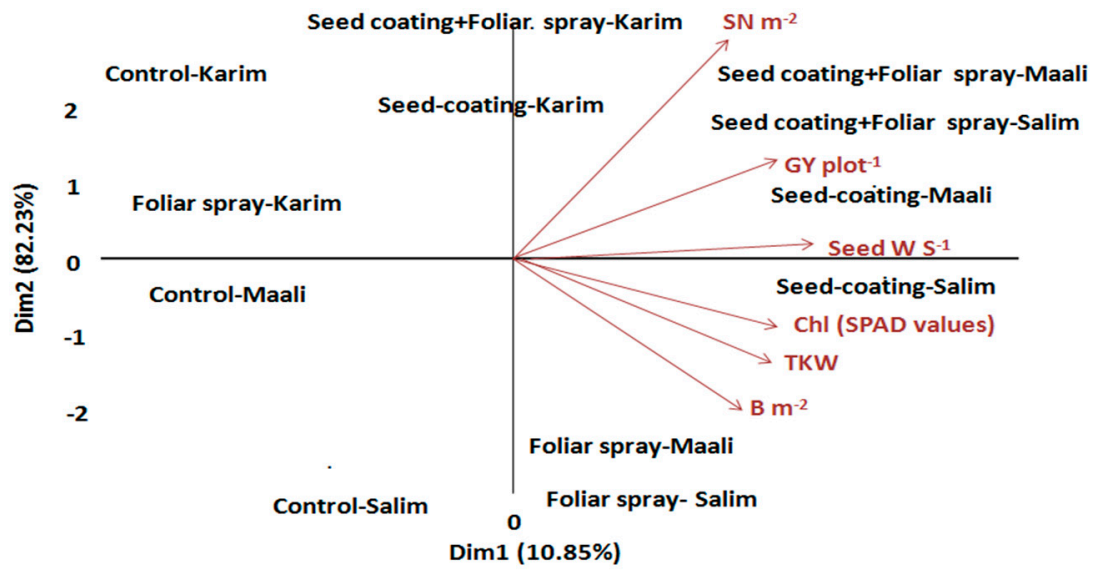

Figure 2. Two-dimensional principal component analysis (PCA) of all combinations (treatmentcultivar) for the germination (a), pot (b) and field (c,d) trials. 


\subsection{Effects of Seed Coating Treatments on Physiological and Agro-Morphological Attributes of Durum Wheat Cultivars Grown under Pot and Field Conditions}

For pot trial, statistical differences ( $p \leq 0.05, p \leq 0.01$, and $p \leq 0.001)$ were obtained among seed coating treatments and cultivars for the relative water content, chlorophyll content, leaf area, biomass, seed number per spike, thousand kernel weight, and grain yield, except the insignificant effect for plant height (Table 2). A significant interaction between treatments and cultivars was noted for almost all traits ( $p \leq 0.05$ and $p \leq 0.01)$, except the relative water content, thousand kernel weight, and grain yield. The application of BS or chemical products to the seeds showed a promising effect on physiological and agro-morphological attributes, while no effect was depicted for the plant height (Table 2, Figure 3). As expected, 'Panoramix' was the most effective seed treatment and enhanced the relative water content $(25 \%)$, chlorophyll content $(13 \%)$, leaf area $(14 \%)$, biomass $(30 \%)$, thousand kernel weight $(19 \%)$, and grain yield $(26 \%)$ compared to the control. This treatment was followed by the combination 'Panoramix + Spectro'. 'Panoramix' and 'Panoramix + Spectro' have more enhanced the biomass and grain yield. Unexpectedly, 'Spectro' (relative water content, plant height, seed number per spike, and thousand kernel weight) and 'Mycoseeds' (chlorophyll content, leaf area, biomass, and grain yield) have slightly improved some traits.

Table 2. Seed coating treatment and cultivar effects on physiological and agro-morphological attributes under pot conditions. For the eight studied variables, the two-way ANOVA is shown according to the different factors.

\begin{tabular}{|c|c|c|c|c|c|c|c|c|c|}
\hline $\begin{array}{l}\text { Sources of } \\
\text { Variation }\end{array}$ & $\mathrm{df}^{\mathbf{1}}$ & RWC (\%) & $\begin{array}{l}\text { Chl (SPAD } \\
\text { Values) }\end{array}$ & LA $\left(\mathrm{cm}^{2}\right)$ & PH (cm) & B Plant $^{-1}(\mathrm{~g})$ & Seed N S -1 & TKW (g) & $\begin{array}{c}\text { GY } \\
\text { Plant }^{-1}(\mathrm{~g})\end{array}$ \\
\hline Treatment (T) & 4 & $3.45 * 2$ & $3.19 *$ & $21.69^{* * *}$ & $1.13^{\mathrm{ns}}$ & $8.93 *$ & $3.22 *$ & $3.21 *$ & $4.93^{* *}$ \\
\hline Cultivar (C) & 2 & $3.52 *$ & $3.78 *$ & $6.28 *$ & $3.57^{\mathrm{ns}}$ & $7.46^{*}$ & $6.11 *$ & $3.31 *$ & $2.83 *$ \\
\hline $\mathrm{T} \times \mathrm{C}$ interaction & 8 & $0.62^{\mathrm{ns}}$ & $2.18 *$ & $2.79 *$ & $3.84 * *$ & $2.03 *$ & $2.48 *$ & $1.48^{\mathrm{ns}}$ & $1.07^{\mathrm{ns}}$ \\
\hline \multicolumn{10}{|c|}{ Treatments } \\
\hline Control & & $55.81 c^{3}$ & $47.74 b$ & $18.48 b$ & $55.22 a$ & $51.42 \mathrm{c}$ & $13.89 b$ & $33.44 \mathrm{c}$ & $14.64 \mathrm{~d}$ \\
\hline Panoramix & & $74.95 a$ & $54.79 a$ & $21.51 \mathrm{a}$ & $54.56 a$ & $73.36 a$ & $16.33 a$ & $41.19 a$ & $19.87 a$ \\
\hline$\left(2 \mathrm{~mL} \mathrm{~kg}^{-1}\right)$ & & $(25 \%)$ & $(13 \%)$ & $(14 \%)$ & $(-1 \%)$ & $(30 \%)$ & $(15 \%)$ & $(19 \%)$ & $(26 \%)$ \\
\hline Spectro & & $\begin{array}{c}56.99 \mathrm{c} \\
(2 \%)\end{array}$ & $\begin{array}{c}51.08 \mathrm{ab} \\
(6 \%)\end{array}$ & $\begin{array}{l}20.87 a \\
(11 \%)\end{array}$ & $\begin{array}{l}52.00 a \\
(-6 \%)\end{array}$ & $\begin{array}{c}54.89 c \\
(6 \%)\end{array}$ & $\begin{array}{c}14.11 \mathrm{~b} \\
(2 \%)\end{array}$ & $\begin{array}{c}35.77 b \\
(6 \%)\end{array}$ & $\begin{array}{c}17.38 \mathrm{ab} \\
(16 \%)\end{array}$ \\
\hline Mycoseeds & & $\begin{array}{c}58.62 \mathrm{ab} \\
(5 \%)\end{array}$ & $\begin{array}{l}47.90 \mathrm{~b} \\
(0.5 \%)\end{array}$ & $\begin{array}{c}19.46 \mathrm{ab} \\
(5 \%)\end{array}$ & $\begin{array}{c}55.00 \mathrm{a} \\
(-0.4 \%)\end{array}$ & $\begin{array}{c}54.80 \mathrm{c} \\
(6 \%)\end{array}$ & $\begin{array}{c}14.33 b \\
(3 \%)\end{array}$ & $\begin{array}{c}37.72 \mathrm{ab} \\
(11 \%)\end{array}$ & $\begin{array}{c}16.13 \mathrm{~cd} \\
(9 \%)\end{array}$ \\
\hline $\begin{array}{l}\text { Panoramix (2 mL } \\
\left.\mathrm{kg}^{-1}\right)+ \text { Spectro }\end{array}$ & & $\begin{array}{c}63.85 \mathrm{ab} \\
(13 \%)\end{array}$ & $\begin{array}{l}48.86 \mathrm{~b} \\
(2 \%)\end{array}$ & $\begin{array}{l}20.90 \mathrm{a} \\
(12 \%)\end{array}$ & $\begin{array}{c}52.11 \mathrm{a} \\
(6 \%)\end{array}$ & $\begin{array}{l}65.88 \mathrm{~b} \\
(22 \%)\end{array}$ & $\begin{array}{c}15.22 \mathrm{ab} \\
(9 \%)\end{array}$ & $\begin{array}{l}39.80 \mathrm{a} \\
(16 \%)\end{array}$ & $\begin{array}{c}18.53 \mathrm{ab} \\
(21 \%)\end{array}$ \\
\hline \multicolumn{10}{|c|}{ Cultivars } \\
\hline Karim & & $54.33 b$ & $46.07 \mathrm{~b}$ & $19.42 \mathrm{a}$ & $56.33 a$ & $52.05 c$ & $14.99 \mathrm{~b}$ & $33.30 \mathrm{~b}$ & $14.99 \mathrm{~b}$ \\
\hline Maali & & $66.18 \mathrm{a}$ & $52.77 a$ & $21.85 \mathrm{a}$ & $55.93 a$ & $67.00 \mathrm{a}$ & $18.88 \mathrm{a}$ & $38.74 a$ & $18.88 \mathrm{a}$ \\
\hline Salim & & $65.62 a$ & $51.38 a$ & $20.27 \mathrm{ab}$ & $55.07 a$ & $61.15 b$ & $18.07 a$ & $39.30 \mathrm{a}$ & $18.07 a$ \\
\hline
\end{tabular}

${ }^{1} \mathrm{df}$ : degree of freedom; RWC: relative water content; Chl: chlorophyll content; LA: leaf area; PH: plant height; plant $^{-1}$ : biomass per plant; Seed N S${ }^{-1}$ : seed number per spike, TKW: thousand kernel weight; GY plant ${ }^{-1}$ : grain yield per plant. ${ }^{2}$ ns: non significatif; ${ }^{*}, * *$, and ${ }^{* * *}$ : significant at $5 \%, 1 \%$, and $0.1 \%$ respectively. ${ }^{3}$ Means with similar letter(s) is not significantly different at $5 \%$ probability level according to Duncan's multiple range test.

The three cultivars responded differently to the seed coating treatments (Table 2, Figure 3). Regardless treatments, 'Maali' followed by 'Salim' showed the highest values for most studied traits. Notably, 'Salim' showed the best performance under 'Panoramix' treatment, but the best increase rates for the relative water content, chlorophyll content, biomass, and seed number per spike were obtained for 'Karim'.

The distribution of 'treatment-cultivar' combinations was performed on the main plan of the PCA where the first two axes (PC-1 and PC-2) presented $83 \%$ of the total variability (Figure 2, Table S2). Based on the identified groups, the results confirmed the noteworthy effect of 'Panoramix' as treatment. This BS seems to act on the similar way on 'Maali' and 'Salim' by enhancing mainly biomass and grain yield. 
(a)
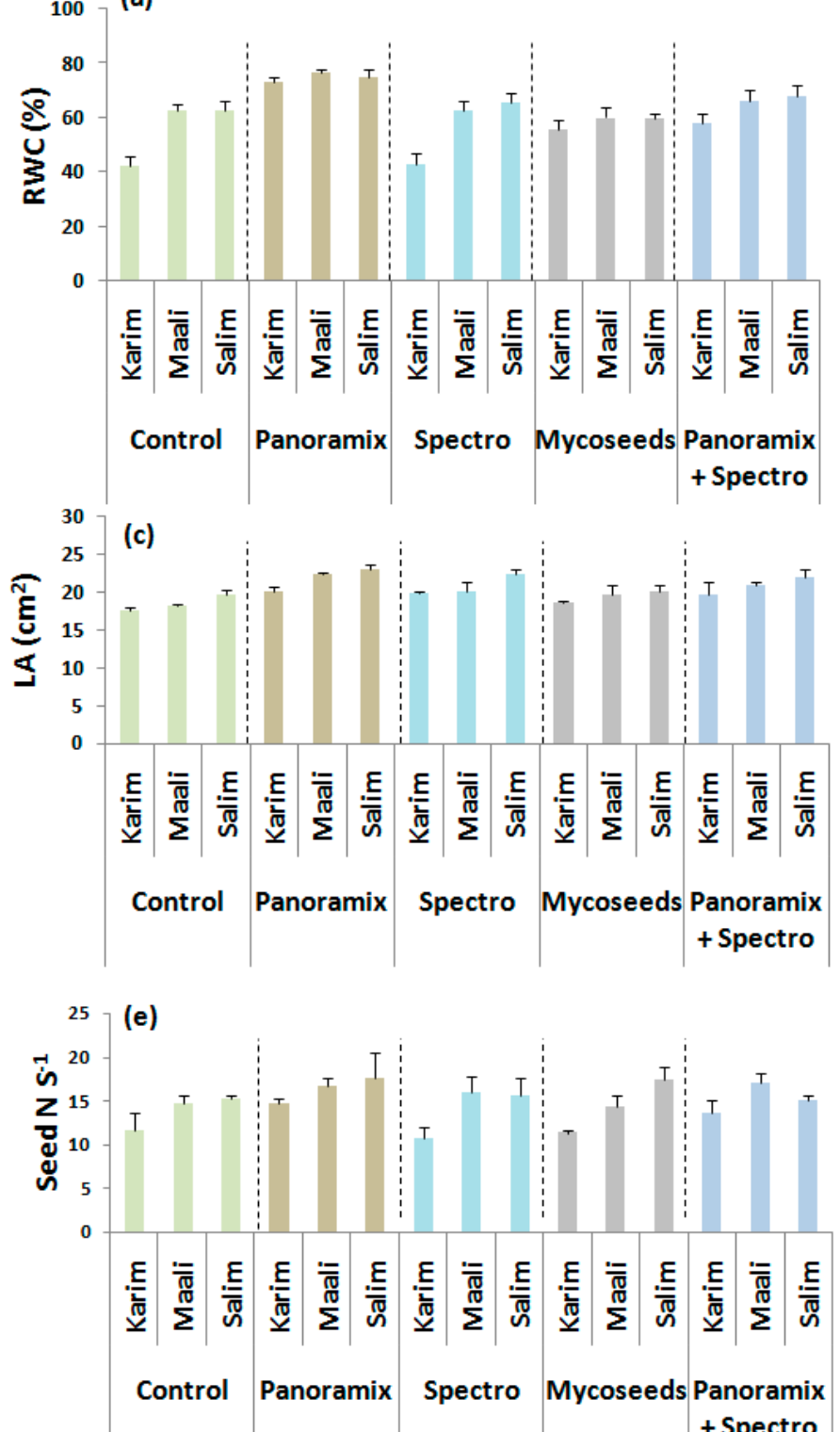

(b)

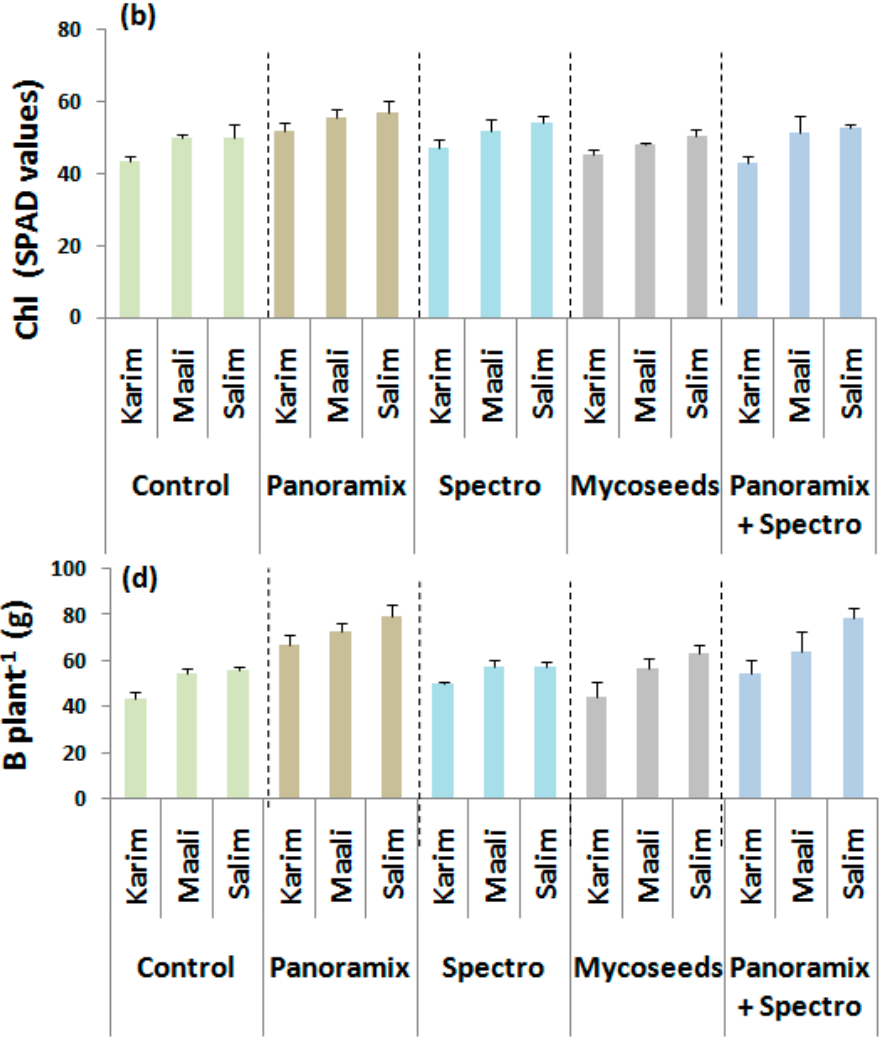

(f)

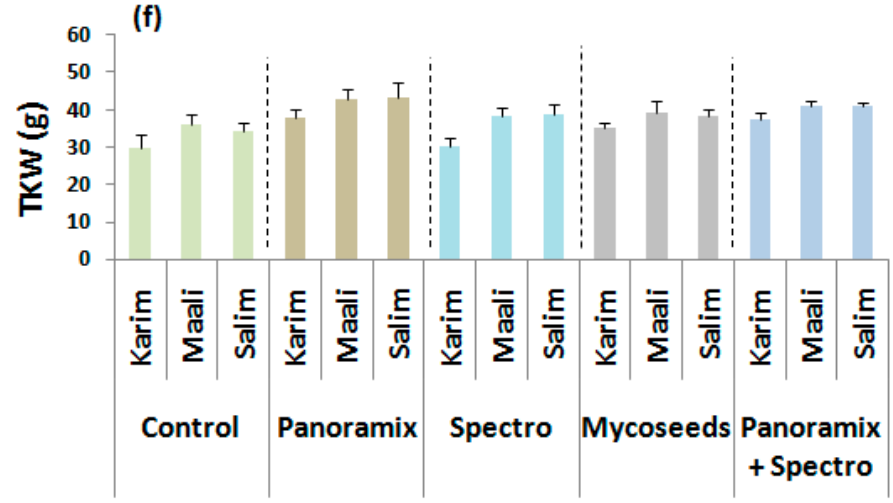

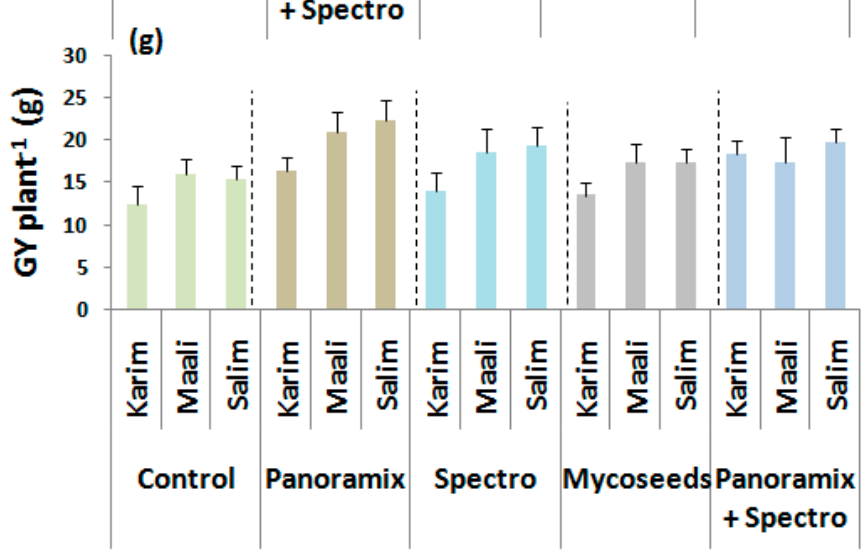

Figure 3. Effects of seed coating treatments on relative water content (RWC, a), chlorophyll content $(\mathrm{Chl}, \mathbf{b})$, leaf area (LA, c), biomass (B plant $\left.{ }^{-1}, \mathbf{d}\right)$, seed number per spike (Seed $\left.\mathrm{N} \mathrm{S}^{-1}, \mathbf{e}\right)$, thousand kernel weight $(\mathrm{TKW}, \mathbf{f})$, and grain yield per plant $\left(\mathrm{GY}\right.$ plant $\left.^{-1}, \mathbf{g}\right)$ of durum wheat cultivars grown under pot conditions. 
For field trial, obtained data showed significant differences $(p \leq 0.05$ and $p \leq 0.001)$ between seed coating treatments for all agro-morphological parameters, except the seed number per spike (Table 3). However, differences between cultivars were only observed for biomass, seed number per spike, and grain yield ( $p \leq 0.05$ and $p \leq 0.01)$. The double interaction between treatments and cultivars was significant $(p \leq 0.001)$ for almost all traits, except the plant height. As shown in pot trial, 'Panoramix' and 'Panoramix + Spectro' showed the highest increase rates for the plant height (5 and 5\%), biomass (12 and 11\%), thousand kernel weight ( 5 and $4 \%$ ), and grain yield (27 and 25\%) (Table 3, Figure 4). The grain yield was the best improved trait by these two treatments. However, 'Spectro' and 'Mycoseeds' showed a poorer performance for the plant height, biomass, and seed number per spike. Under semi-arid environment, 'Salim' followed by 'Maali' responded better to seed coating treatments. Nonetheless, under 'Panoramix' treatment, the highest increase rates for grain yield and plant height were observed for 'Karim'.

Table 3. Seed coating treatment and cultivar effects on agro-morphological attributes under field conditions. For the five studied variables, the two-way ANOVA is shown according to the different factors.

\begin{tabular}{|c|c|c|c|c|c|c|}
\hline Sources of Variation & $\mathrm{df}^{1}$ & $\mathrm{PH}(\mathrm{cm})$ & B Plant $^{-1}$ (g) & Seed N S -1 & TKW (g) & $\mathrm{GY} \mathrm{m}^{-1}(\mathrm{~g})$ \\
\hline Treatment (T) & 4 & $2.49 * 2$ & $32.21 * * *$ & $2.60^{\mathrm{ns}}$ & $20.49^{* * *}$ & $10.89^{* * *}$ \\
\hline Cultivar (C) & 2 & $0.39^{\mathrm{ns}}$ & $6.10 * *$ & $2.37 *$ & $0.37^{\mathrm{ns}}$ & $4.30 *$ \\
\hline $\mathrm{T} \times \mathrm{C}$ interaction & 8 & $0.44^{\mathrm{ns}}$ & $9.66^{* * *}$ & $8.92^{* * *}$ & $8.04^{* * *}$ & $4.46^{* * *}$ \\
\hline \multicolumn{7}{|c|}{ Treatments } \\
\hline Control & & $52.67 c^{3}$ & $129.16 a$ & $20.06 a$ & $36.05 b$ & $36.41 c$ \\
\hline Panoramix $\left(2 \mathrm{~mL} \mathrm{~kg}^{-1}\right)$ & & $55.44 a(5 \%)$ & $\begin{array}{c}147.59 a \\
(12 \%)\end{array}$ & $\begin{array}{l}23.28 \mathrm{a} \\
(14 \%)\end{array}$ & $38.17 \mathrm{a}(5 \%)$ & $\begin{array}{l}49.58 \mathrm{a} \\
(27 \%)\end{array}$ \\
\hline Spectro & & $54.78 \mathrm{ab}(4 \%)$ & $\begin{array}{c}129.09 \mathrm{a} \\
(0.1 \%)\end{array}$ & $\begin{array}{c}19.94 \mathrm{a} \\
(1 \%)\end{array}$ & $36.36 b(1 \%)$ & $\begin{array}{c}40.08 \mathrm{bc} \\
(9 \%)\end{array}$ \\
\hline Mycoseeds & & $52.56 \mathrm{c}(0.2 \%)$ & $\begin{array}{c}129.81 \mathrm{a} \\
(0.5 \%)\end{array}$ & $\begin{array}{l}22.72 \mathrm{a} \\
(12 \%)\end{array}$ & $36.39 b(1 \%)$ & $\begin{array}{l}43.02 \mathrm{~b} \\
(15 \%)\end{array}$ \\
\hline $\begin{array}{c}\text { Panoramix }\left(2 \mathrm{~mL} \mathrm{~kg}^{-1}\right)+ \\
\text { Spectro }\end{array}$ & & $55.67 a(5 \%)$ & $\begin{array}{c}145.96 a \\
(11 \%)\end{array}$ & $\begin{array}{c}20.89 a \\
(4 \%)\end{array}$ & $37.38 \mathrm{ab}(4 \%)$ & $\begin{array}{l}48.31 \mathrm{a} \\
(25 \%)\end{array}$ \\
\hline \multicolumn{7}{|c|}{ Cultivars } \\
\hline Karim & & $52.67 a$ & $121.18 \mathrm{c}$ & $21.80 \mathrm{ab}$ & $35.12 \mathrm{a}$ & $40.30 \mathrm{~b}$ \\
\hline Maali & & $54.60 \mathrm{a}$ & $136.52 b$ & $22.67 a$ & $37.66 \mathrm{a}$ & $43.72 \mathrm{ab}$ \\
\hline Salim & & $54.20 \mathrm{a}$ & $148.08 \mathrm{a}$ & $19.67 \mathrm{~b}$ & $38.04 a$ & $45.03 a$ \\
\hline
\end{tabular}

${ }^{1}$ df: degree of freedom; PH: plant height; B plant ${ }^{-1}$ : biomass per plant; Seed $\mathrm{N} \mathrm{S}^{-1}$ : seed number per spike; TKW: thousand weight kernel; GY m${ }^{-1}$ : grain yield per linear meter. ${ }^{2}$ ns: non significatif; ${ }^{*},{ }^{* *}$, and ${ }^{* * *}$ : significant at $5 \%, 1 \%$, and $0.1 \%$, respectively. ${ }^{3}$ Means with similar letter(s) is not significantly different at $5 \%$ probability level according to Duncan's multiple range test.

Based on PCA results, the PC- 1 and PC-2 presented $87 \%$ of the total variability (Figure 2, Table S3). This analysis showed that the three durum wheat cultivars acted to 'Panoramix', chemicals and combined treatment. This made it possible to group these treatments into the same group for each cultivar. The superiority of 'Panoramix' is clearly visible within each group.

\subsection{Effectiveness of Biostimulant Supply Methods}

The results revealed significant $(p \leq 0.05, p \leq 0.01$, and $p \leq 0.001$ ) effect of the applied BS methods on chlorophyll content, biomass, seed weight per spike, spike number, thousand kernel weight, and grain yield (Table 4). Differences between cultivars were noted for the biomass, spikelet number per spike, seed weight per spike, thousand kernel weight, and grain yield. In addition, significant $(p \leq 0.05$ and $p \leq 0.001)$ interactions between the main factors were observed for biomass and grain yield. Under semi-arid conditions, the application of BS with various methods increased most traits compared to the control (Table 4, Figure 5). Interestingly, the combined methods 'seed coating + foliar 
spray' enhanced the chlorophyll content, biomass, spike number, seed weight per spike, thousand kernel weight, and grain yield by $54,11,10,32,10$, and $24 \%$, respectively. This treatment was followed by the 'seed coating' method. Globally, seed weight per spike followed by grain yield were the most enhanced traits by the three methods. Considering the tested durum wheat cultivars, 'Salim' was the best performing genotype in most cases.

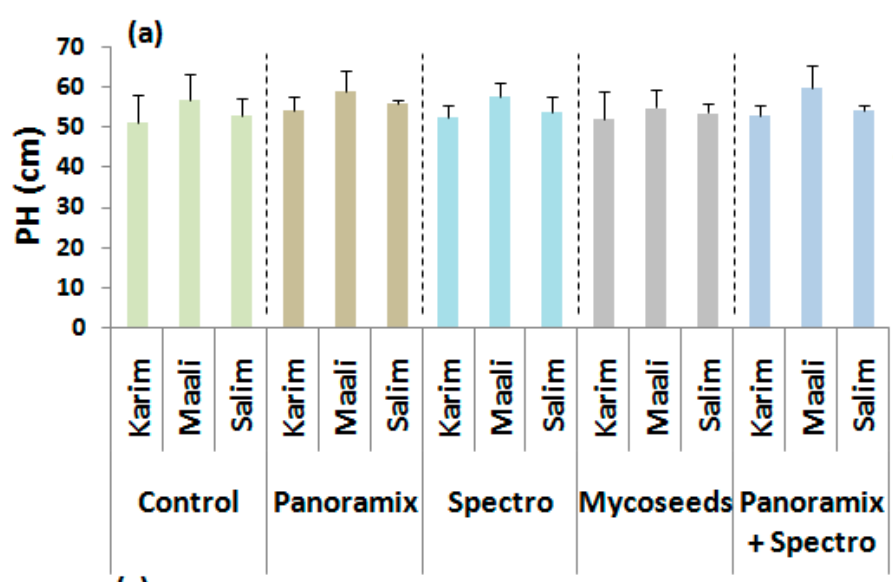

(c)

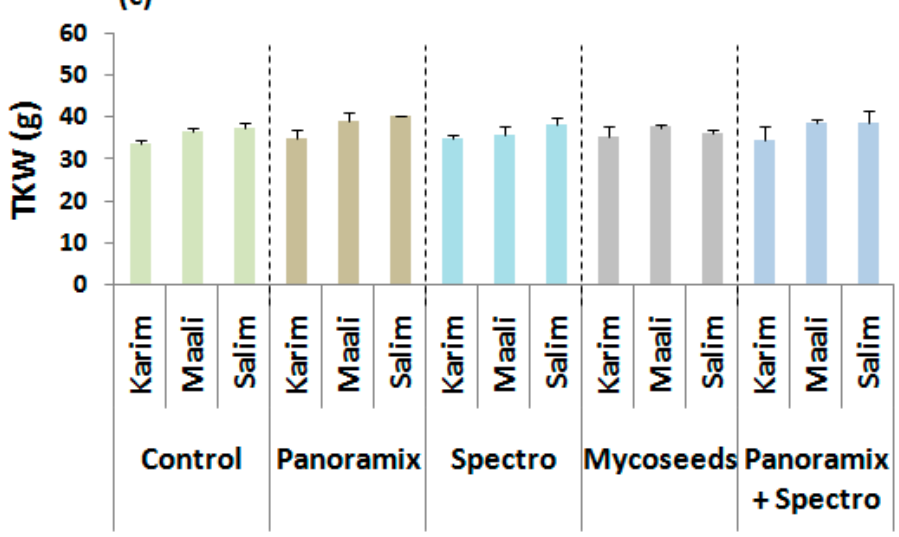

(b)

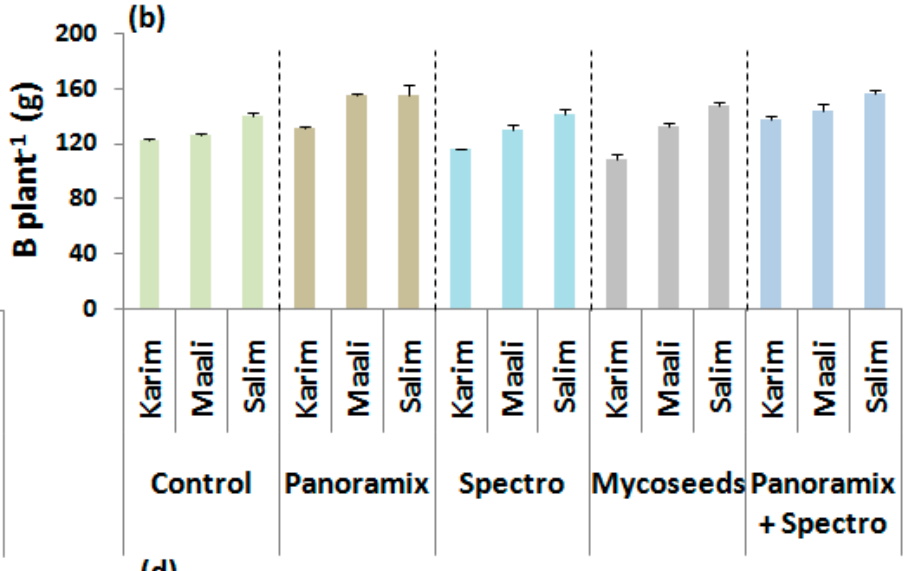

(d)

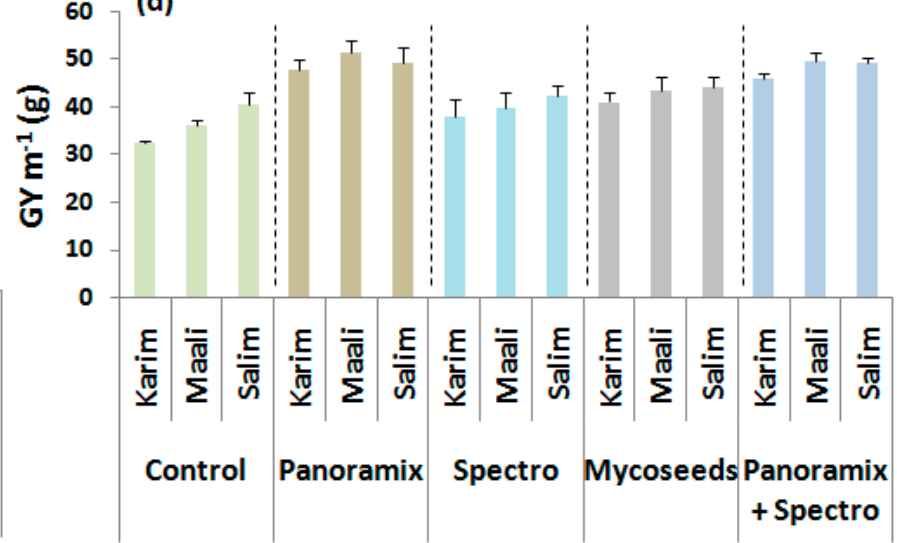

Figure 4. Effects of seed coating treatments on plant height $(\mathrm{PH}, \mathbf{a})$, biomass per plant $\left(\mathrm{B} \mathrm{plant}^{-1}, \mathbf{b}\right)$, thousand kernel weight $(\mathrm{TKW}, \mathbf{c})$, and grain yield per linear meter $\left(\mathrm{GY} \mathrm{m}^{-1}, \mathbf{d}\right)$ of durum wheat cultivars grown under field conditions.

Table 4. Biostimulant supply method and cultivar effects on physiological and agro-morphological attributes under field conditions. For the nine studied variables, the two-way ANOVA is shown according to the different factors.

\begin{tabular}{|c|c|c|c|c|c|c|c|c|c|c|}
\hline $\begin{array}{l}\text { Sources of } \\
\text { Variation }\end{array}$ & $\mathrm{df}^{1}$ & $\begin{array}{c}\text { Chl } \\
\text { (SPAD } \\
\text { Values) }\end{array}$ & $\begin{array}{c}\mathrm{PH} \\
(\mathrm{cm})\end{array}$ & $\begin{array}{c}\mathrm{B} \mathrm{m}^{-2} \\
(\mathrm{~g})\end{array}$ & $\mathrm{SN} \mathrm{m} \mathrm{m}^{-2}$ & $\begin{array}{c}\text { Spk N } \\
S^{-1}\end{array}$ & $\begin{array}{c}\text { Seed N } \\
S^{-1}\end{array}$ & $\begin{array}{l}\text { Seed W } \\
S^{-1}(g)\end{array}$ & $\begin{array}{c}\text { TKW } \\
\text { (g) }\end{array}$ & $\begin{array}{c}\text { GY m} ~^{-2} \\
(\mathrm{~g})\end{array}$ \\
\hline Treatment & 3 & $6.96 * * * 2$ & $0.98^{\mathrm{ns}}$ & $8.87^{* * *}$ & 111.14 ** & $0.25^{\mathrm{ns}}$ & $0.55^{\mathrm{ns}}$ & $5.12 * *$ & 1.34 * & $73.59 * * *$ \\
\hline Cultivar & 2 & $0.49^{\mathrm{ns}}$ & $3.08^{\mathrm{ns}}$ & $5.61^{* * *}$ & $1.42^{\mathrm{ns}}$ & $3.77 *$ & $0.46^{\mathrm{ns}}$ & $1.40 * *$ & $0.53 *$ & $0.08^{* *}$ \\
\hline $\begin{array}{c}\mathrm{T} \times \mathrm{C} \\
\text { interaction }\end{array}$ & 6 & $0.42^{\mathrm{ns}}$ & $1.48^{\mathrm{ns}}$ & $10.40 * * *$ & $0.68^{\mathrm{ns}}$ & $1.37^{\mathrm{ns}}$ & $1.45^{\mathrm{ns}}$ & $1.76^{\mathrm{ns}}$ & $1.06^{\mathrm{ns}}$ & $2.92 *$ \\
\hline \multicolumn{11}{|c|}{ Treatments } \\
\hline Control & & $48.58 \mathrm{a}^{3}$ & $66.19 a$ & $1430 \mathrm{~b}$ & $283.00 c$ & $12.52 b$ & $18.48 \mathrm{a}$ & $6.03 b$ & $39.83 b c$ & $252310 b$ \\
\hline Seed coating & & $\begin{array}{c}51.96 \mathrm{ab} \\
(6 \%)\end{array}$ & $\begin{array}{c}64.00 \mathrm{a} \\
(3 \%)\end{array}$ & $\begin{array}{l}1600 a \\
(11 \%)\end{array}$ & $\begin{array}{c}302.41 \mathrm{~b} \\
(6 \%)\end{array}$ & $\begin{array}{l}15.62 a \\
(20 \%)\end{array}$ & $\begin{array}{c}18.48 \mathrm{a} \\
(0 \%)\end{array}$ & $\begin{array}{l}8.38 \mathrm{a} \\
(28 \%)\end{array}$ & $\begin{array}{c}44.20 \mathrm{ab} \\
(10 \%)\end{array}$ & $\begin{array}{c}325380 a \\
(22 \%)\end{array}$ \\
\hline Foliar spray & & $\begin{array}{c}51.44 a b \\
(6 \%)\end{array}$ & $\begin{array}{l}66.44 a \\
(0.4 \%)\end{array}$ & $\begin{array}{c}1490 \mathrm{~b} \\
(4 \%)\end{array}$ & $\begin{array}{c}282.15 c \\
(0.3 \%)\end{array}$ & $\begin{array}{c}13.75 \mathrm{~b} \\
(9 \%)\end{array}$ & $\begin{array}{c}17.93 a \\
(3 \%)\end{array}$ & $\begin{array}{c}7.56 a b \\
(20 \%)\end{array}$ & $\begin{array}{c}42.67 \mathrm{bc} \\
(7 \%)\end{array}$ & $\begin{array}{c}314780 \mathrm{a} \\
(20 \%)\end{array}$ \\
\hline
\end{tabular}


Table 4. Cont.

\begin{tabular}{|c|c|c|c|c|c|c|c|c|c|c|}
\hline $\begin{array}{l}\text { Sources of } \\
\text { Variation }\end{array}$ & $\mathrm{df}^{1}$ & $\begin{array}{c}\text { Chl } \\
\text { (SPAD } \\
\text { Values) }\end{array}$ & $\begin{array}{l}\mathrm{PH} \\
(\mathrm{cm})\end{array}$ & $\begin{array}{c}B \mathrm{~m}^{-2} \\
(\mathrm{~g})\end{array}$ & $\mathrm{SN} \mathrm{m} \mathbf{m}^{-2}$ & $\begin{array}{c}\text { Spk N } \\
S^{-1}\end{array}$ & $\begin{array}{c}\text { Seed N } \\
S^{-1}\end{array}$ & $\begin{array}{l}\text { Seed W } \\
S^{-1}(g)\end{array}$ & $\begin{array}{c}\text { TKW } \\
\text { (g) }\end{array}$ & $\begin{array}{c}\mathrm{GY} \mathrm{m^{-2 }} \\
(\mathrm{g})\end{array}$ \\
\hline $\begin{array}{l}\text { Seed coating } \\
+ \text { Foliar } \\
\text { spray }\end{array}$ & & $\begin{array}{c}53.62 a \\
(9 \%)\end{array}$ & $\begin{array}{c}64.11 \mathrm{a} \\
(3 \%)\end{array}$ & $\begin{array}{l}1610 a \\
(11 \%)\end{array}$ & $\begin{array}{c}315.19 a \\
(10 \%)\end{array}$ & $\begin{array}{l}15.47 a \\
(19 \%)\end{array}$ & $\begin{array}{l}16.59 a \\
(10 \%)\end{array}$ & $\begin{array}{l}8.94 a \\
(32 \%)\end{array}$ & $\begin{array}{l}44.40 \mathrm{a} \\
(10 \%)\end{array}$ & $\begin{array}{c}331920 a \\
(24 \%)\end{array}$ \\
\hline \multicolumn{11}{|c|}{ Cultivars } \\
\hline Karim & & $48.83 b$ & $66.39 a$ & $1400 \mathrm{~b}$ & $294.78 b$ & $12.77 \mathrm{~b}$ & $17.61 b$ & $6.57 \mathrm{~b}$ & $40.61 b$ & $291690 b$ \\
\hline Maali & & $52.44 a$ & $66.31 \mathrm{a}$ & $1550 \mathrm{ab}$ & $297.50 a$ & $15.07 \mathrm{a}$ & $17.33 b$ & $8.09 a$ & $43.66 a$ & $312030 a$ \\
\hline Salim & & $52.93 a$ & $62.86 a$ & $1660 a$ & $294.78 b$ & $15.17 \mathrm{a}$ & $18.67 \mathrm{a}$ & $8.26 a$ & $44.06 a$ & 314 570a \\
\hline
\end{tabular}

${ }^{1} \mathrm{df}$ : freedom degree; $\mathrm{Chl}$ : chlorophyll content; $\mathrm{PH}$ : plant height; $\mathrm{B} \mathrm{m}^{-2}$ : biomass per $\mathrm{m}^{-2} ; \mathrm{SN} \mathrm{m}^{-2}$ : spike number per $\mathrm{m}^{-2}$; SpkN S${ }^{-1}$ : spikelet number per spike; Seed N S${ }^{-1}$ : seed number per spike; Seed $\mathrm{W} \mathrm{S}^{-1}$ : seed weight per spike; TKW: thousand kernel weight; GY ${ }^{-2}$ : grain yield per $\mathrm{m}^{2} .{ }^{2} \mathrm{~ns}$ : non significatif; ${ }^{*}, * *$, and ${ }^{* * *}$ : significant at $5 \%, 1 \%$, and $0.1 \%$, respectively. ${ }^{3}$ Means with similar letter(s) is not significantly different at $5 \%$ probability level according to Duncan's multiple range test.
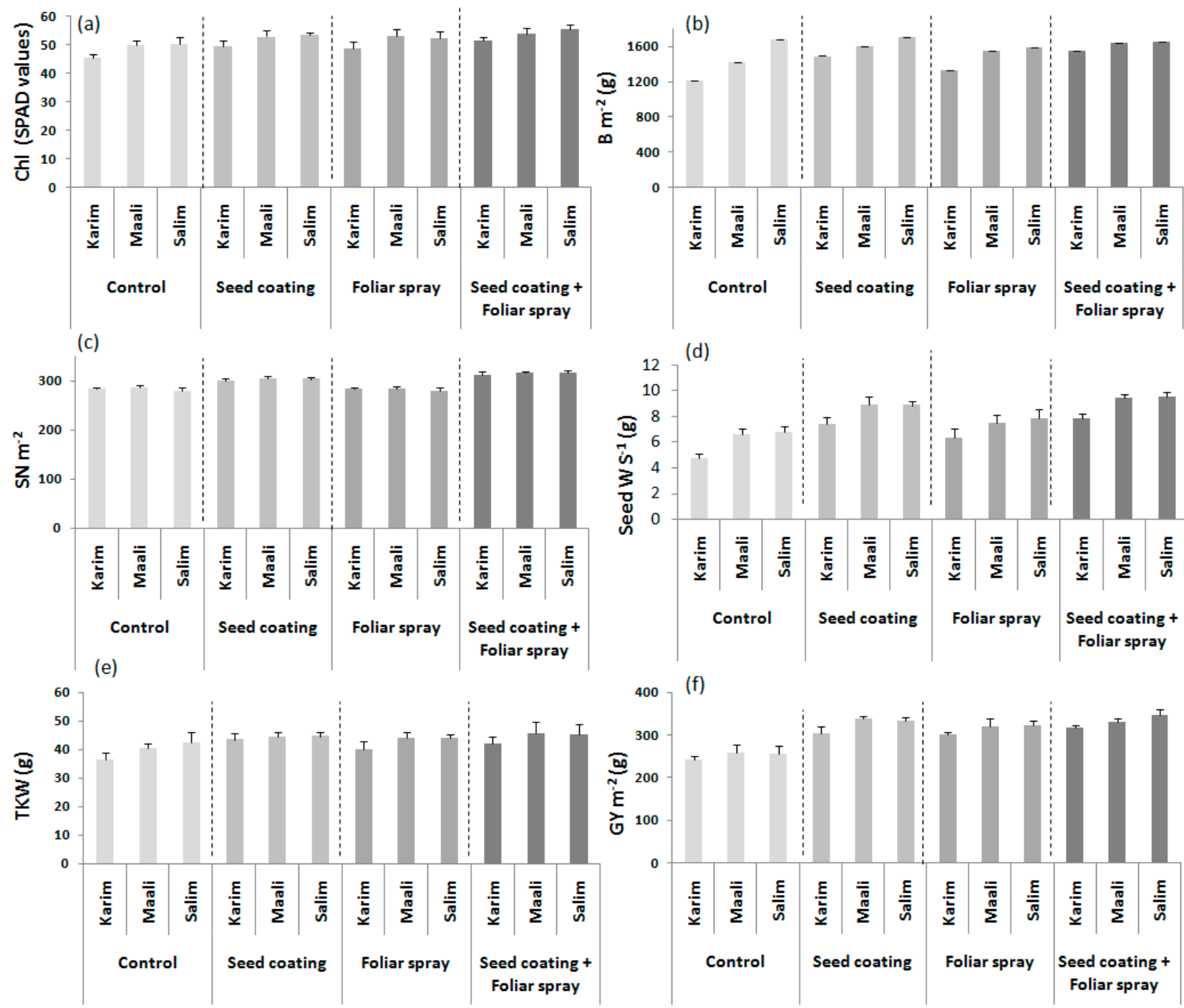

Figure 5. Effects of biostimulant supply methods on chlorophyll content (Chl, a), biomass per $\mathrm{m}^{-2}\left(\mathrm{~B} \mathrm{~m}^{-2}, \mathbf{b}\right)$, spike number per $\mathrm{m}^{-2}\left(\mathrm{SN} \mathrm{m}^{-2}, \mathbf{c}\right)$, seed weight per spike (Seed $\left.\mathrm{W} \mathrm{S}^{-1}, \mathbf{d}\right)$, thousand kernel weight (TKW, e), and grain yield per $\mathrm{m}^{2}\left(\mathrm{GY} \mathrm{m}^{-2}, \mathbf{f}\right)$ of durum wheat cultivars grown under field conditions. 
For the PCA, PC1 and PC2 accounted for 93\% of the total variability (Figure 2, Table S4). This analysis showed on one hand that the responses of 'Salim' and 'Maali' were very close using the three techniques ('seed coating', 'foliar spray' and 'seed coating + foliar spray'), and on other hand the high efficiency of the combined method, in particular for 'Salim' and 'Maali'.

\section{Discussion}

3.1. Promising Effect of the Biostimulant 'Panoramix' on Durum Wheat Germination, Physiological, and Agro-Morphological Performances

Under different experimental conditions, the use of the BS 'Panoramix' showed a promising effect on germination, physiological, and agro-morphological attributes compared to the control and chemical products. Therefore, these findings highlight the beneficial effect of the BS, containing a mix of eukaryotic and prokaryotic microorganisms, on plants.

The seed coating could be an effective approach to help plants in germination process. In the present research, the BS 'Panoramix' was the most efficient treatment for the germination attributes (i.e., germination rate, coleoptile length, and root length), in particular using $2 \mathrm{~mL} \mathrm{~kg}^{-1}$. These results might be explained by the additive and/or synergetic effect of Bacillus spp., Trichoderma spp., and AM fungi. In fact, seed coating with saprophytic fungi such as Trichoderma harzianum, enhanced the germination rate, shoot and root length, and seed vigor of 'Karim' cultivar [31]. In addition, these authors noted an increase in the total phenolic content and peroxidase activity in leaves. More specifically, inoculation with T. harzianum enhanced phase III imbibitions; i.e., cell elongation followed by radicle protrusion [32]. The promotive effect of Trichoderma on wheat seed germination was attributed to increasing gibberellic acid (GA3) that boosts up the activity of hydrolytic and proteolytic enzymes acting to mobilize the food reserves from the cotyledons or endosperm [33]. Otherwise, Bacillus spp. as with Bacillus subtilis QM3 increased the isoenzyme activity, $\beta$-amylase that may be one of the key factors to promote the germination of wheat seeds [34]. The same strain enhanced the antioxidant activities of wheat seeds under salt stress [35].

Unlike chemicals, 'Panoramix' enhanced the radicle growth more than the coleoptile growth. This result was probably due to the fact that, when the Trichoderma hyphae colonizes and establishes a close relationship with roots, this fungus increases the specific area and robustness of this organ [32,36]. In fact, T. harzianum found along the root surfaces and underneath the outermost layer of root cells, released auxin, harzianolide, and harzianic acid [37]. These secondary metabolites promote better the root development (root length and root tips) [38-40] allowing to explore a bigger region of soil [26]. Subsequently, the proper development of a root system during germination, as observed in this study, should influence the ability of a good seedling establishment and the further course of seedling growth.

Under semi-arid conditions, 'Panoramix' $\left(2 \mathrm{~mL} \mathrm{~kg}^{-1}\right)$ still the best seed coating treatment for durum wheat cultivars. Notably, the individual application of 'Panoramix' performs better than the combined application with 'Spectro'. The positive role of the BS was noted for the three physiological parameters including the relative water content, the chlorophyll content, and the leaf area. In addition, a beneficial effect of the BS on biomass, grain yield and its related components (i.e., seed number per spike and thousand kernel weight) was observed. The induced mechanisms by Bacillus, Trichoderma or AM fungi might explain the improvement of physiological activity, growth, and yield. In fact, Bacillus spp., one of the predominant PGPRs, are known to be associated with roots or rhizosphere and develop biofilms that trigger plant growth and prevent pathogen infection [6,41]. Bacillus spp. manipulate the intracellular phytohormone metabolism by the synthesis of indole3-acetic acid (IAA), gibberellic acid, cytokinins, and 1-aminocyclopropane-1-carboxylate (ACC) deaminase [42-45]. In particular, IAA has important effects on root growth [46] and architecture [47], while the secretion of ACC deaminase inhibits ethylene synthesis in crop plants and promotes root as well as shoot cell division and elongation $[44,48]$. In addition, 
Bacillus spp. produce exopolysaccharides and siderophores, which prevent the movement of toxic ions, adjust the ionic balance, water transport in plant tissues and the activation of the antioxidant and defense systems [41]. Some Bacillus spp. enhance the nutrient uptake and content in plant tissues [49-53]. Otherwise, the success of Bacillus spp. is due in part to its ability to modify the rhizosphere. The hasten growth of plant induced by Bacillus spp. might increase the abundance and the activity of this microbial population through the secretion of significant amounts of root exudates [54]. This will in turn increase the availability of nutrients for the microbial consumption. Enhanced microbial activity will have therefore a positive effect on nutrient bioavailability.

Similar to Bacillus spp., Trichoderma spp. are well known for their ability to produce a wide range of plant-growth promoting substances (secondary metabolites, phytohormones [e.g., IAA and their analogous], vitamins, and enzymes) [55]. These Trichoderma-induced mechanisms can influence several aspects of plant development including plant growth and root architecture (increase in the length of lateral and primary root), and nutritional status (increase in nutrient uptake and use efficiency) [11,12,17,55]. As shown for Bacillus spp., applying Trichoderma spp. to the soil stimulates the root exudation to promote both microbial and plant growth [56]. Moreover, Trichoderma spp. produce organic acids in rhizosphere such as gluconic, citric, and/or fumaric acids that decrease soil pH [7].

Otherwise, endomycorrhiza, one of the components of 'Panoramix' product, has also been shown to improve productivity of numerous crop plants [16], including wheat [57]. In this sense, Zhang et al. [58] reported that inoculation of AM fungi in field increased grain yield by $16 \%$. This symbiotic fungus promotes plant growth by producing metabolites and increasing the acquisition of immobile nutrients such as phosphorus, zinc, and copper beyond the range of plant roots via their hyphae $[16,17]$. Moreover, other factors associated with AM fungi colonization may influence plant resistance to drought. These factors include changes in leaf elasticity, improving leaf water and turgor potentials, maintaining the stomatal opening and transpiration, increasing root length and depth, and adventice root formation $[59,60]$. According to Adesemoye et al. [61], the combined inoculation of a strain of AM fungi with two PGPR strains (Bacillus amyloliquefaciens and Bacillus pumilus), used as a complementary mineral fertilization, can reduce the use of conventional fertilizer by $25 \%$.

\subsection{Genotypic Variation against Seed and Foliar Treatments}

For the germination, pot, and field trials, meaningful and consistent differences between durum wheat cultivars were observed in their response to seed coating treatments or BS supply methods. At germination stage and regardless the seed treatments, 'Salim' showed the best germination rate, while 'Maali' displayed the highest coleoptile and root length. Under pot conditions, 'Maali' exhibited also the best values for physiological and agro-morphological traits, but 'Salim' outperformed the others genotypes using 'Panoramix'. 'Salim' was also the best genotype under field conditions for most treatments including 'Panoramix' and responded better to the three methods of BS application. This variation might be explained by the genetic variability of the plant species whose seeds were treated by the mix of Bacillus spp., Trichoderma spp., and AM fungi, as well as their interaction that might influence the action mechanisms of microorganisms. In summary, the best performance was obtained for 'Salim' with 'Panoramix', but it was not the only genotype that best valorized this BS. Indeed, for some parameters, 'Karim' showed the highest increase rates.

\subsection{Effectiveness of Biostimulant Depends on the Supply Methods}

In most cases, the three BS supply methods enhanced the physiological and agromorphological attributes. The present investigation showed also differences among methods of BS application. The combined technique, 'seed coating + foliar spray' was found more effective than the individual applications. The results corroborate with those of Norrie and Keathley [62], Gajc-Wolska et al. [63], and Sharma et al. [64] who depicted that spray 
application and seed priming boost photosynthetic activity and increase yield of several species. Otherwise, the individual effect of BS using the 'seed coating' technique showed a better performance compared to the 'foliar spray', contrary to Amutha et al. [65]. Indeed, seed coating, a process that consists in covering seeds with low amounts of exogenous materials, is gaining attention as an efficient delivery system for beneficial microoragnisms [17]. The coating method facilitates the contact between the treatment and the seed [66,67]. This will help beneficial microorganisms to successfully colonize the roots to obtain subsequently healthy, homogeneous and robust seedlings with better nutrients uptake, which constitutes the solid foundation for high yield potential. The colonization of roots at early germination stage might explain the advantageous effect of 'seed coating' compared to 'foliar spray' technique. In addition, 'seed coating' with a bacterial formulation might deliver higher bacterial concentration to the seeds and consequently to the rhizosphere, in comparison with other methods [17].

\section{Materials and Methods}

\subsection{Vegetal Material}

Three modern durum wheat cultivars (Triticum durum Desf.), namely 'Karim', 'Maali', and 'Salim' were used in this study. 'Karim' (control) and 'Maali' were the most cultivated cultivars in Tunisia, while 'Salim' is a new cultivar that was marketed for farmers since 2019-2020 cropping season. The main characteristics of the cultivars are presented in Table S5.

\subsection{Seed Manipulation and Applied Treatments}

The seeds of each cultivar were surface-sterilized with $10 \%$ sodium hypochlorite solution for $5 \mathrm{~min}$, and washed three times ( $5 \mathrm{~min}$ each) with distilled water. Afterwards, seeds were soaked for the hydro-priming ([control], distilled water) or coated with (i) a BS named 'Panoramix' (Koppert Biological Systems, Rotterdam, The Netherlands), (ii) a chemical product, 'Spectro' or 'Mycoseeds', or (iii) the combination of two products 'Panoramix' and 'Spectro' (Table 5). The seeds were placed in gripseal bag and allowed to air before sealing the bag. Then, the bags were shaken to spread the coating material as evenly as possible over the seeds, approximately $30 \mathrm{~s}$ to $1 \mathrm{~min}$, and continuous aeration was provided to avoid anxious conditions. For germination bioassay, three BS concentrations $(2,4$, and $6 \mathrm{~mL} \mathrm{~kg}^{-1}$ seeds) were tested in order to discern the most effective concentration (Table 5). For the combined treatment, 'Panoramix + Spectro', the recommended concentrations were used for both products (i.e., $4 \mathrm{~mL} \mathrm{~kg}^{-1}$ for 'Panoramix', see Table 5 for 'Spectro'). However, based on germination results, the concentration of $2 \mathrm{~mL} \mathrm{~kg}^{-1}$ was used for the individual or combined effect of 'Panoramix' for the following trials.

Table 5. Composition and quantities of products used.

\begin{tabular}{|c|c|c|}
\hline Products & Composition & Quantities \\
\hline Panoramix & $\begin{array}{l}\text { Mix of Bacillus spp. }\left(2 \times 10^{7} \mathrm{CFU} \mathrm{mL}^{-1}\right) \text {, } \\
\text { Trichoderma spp. }\left(>1 \times 10^{7} \mathrm{CFU} \mathrm{mL}^{-1}\right) \text {, } \\
\text { endomycorrhiza }\left(>10 \text { propagules } \mathrm{mL}^{-1}\right) \\
\text { and additives }\end{array}$ & $\begin{array}{l}2 \mathrm{~mL} \text { per } \mathrm{kg} \text { of seeds } \\
4 \mathrm{~mL} \text { per } \mathrm{kg} \text { of seeds } \\
6 \mathrm{~mL} \text { per } \mathrm{kg} \text { of seeds }\end{array}$ \\
\hline Mycoseeds FS 60 & $60 \mathrm{~g} \mathrm{~L}^{-1}$ Tebuconazole & $\begin{array}{l}0.5 \mathrm{~mL} \text { of product }+5 \mathrm{~mL} \text { of } \\
\text { water per } \mathrm{kg} \text { of seeds }\end{array}$ \\
\hline $\begin{array}{l}\text { Spectro extreme } \\
115 \mathrm{FS}\end{array}$ & $\begin{array}{l}92 \mathrm{~g} \mathrm{~L}^{-1} \text { Difenoconazole }+23 \mathrm{~g} \mathrm{~L}^{-1} \\
\text { Métalaxyl-M }\end{array}$ & $\begin{array}{l}0.65 \mathrm{~mL} \text { of product }+5 \mathrm{~mL} \text { of } \\
\text { water per } \mathrm{kg} \text { of seeds }\end{array}$ \\
\hline
\end{tabular}

4.3. Effectiveness of Biostimulant vs. Chemical Products Using Seed Coating Technique

\subsubsection{Seed Germination Bioassay}

In this experiment, seven seed coating treatments were considered: Control (distilled water), 'Panoramix' (2, 4 and $6 \mathrm{~mL} \mathrm{~kg}^{-1}$ seeds), 'Spectro', 'Mycoseeds', and 'Panoramix $\left(4 \mathrm{~mL} \mathrm{~kg}{ }^{-1}\right.$ seeds $)+$ Spectro'. Thereafter, ten coated/non-coated seeds were placed on 
sterile filter paper $\left(12-15 \mu \mathrm{m}\right.$, sterilized at $120^{\circ} \mathrm{C}$ for $\left.1 \mathrm{~h}\right)$ in a $90 \mathrm{~mm}$ diameter Petri dish moistened with $4 \mathrm{~mL}$ of distilled water. Seeds were germinated in dark growth chamber, at $50 \%$ relative humidity and an average day/night temperature of $22 \pm 2{ }^{\circ} \mathrm{C}$. The completely randomized block design with three replications $(n=3)$ was adopted, to accommodate the two-way factorial experiment with seven seed coating treatments and three durum wheat cultivars as main factors.

\subsubsection{Pot and Field Experiments under Semi-Arid Conditions}

Pot and field trials were conducted during 2016/17 cropping season at Boulifa/Kef

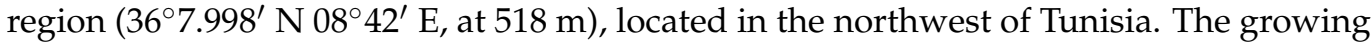
season temperature and precipitation data were recorded at the meteorological station of the Kef region. The experimental area has a semi-arid climate with a mean temperature and precipitation varied between 6.65 and $28.35^{\circ} \mathrm{C}$, and 2 to $51 \mathrm{~mm}$ from October 2016 to July 2017 (Table S6). The soil of the experimental station is classified as sandy-loam [68] with 98.00 ppm N, 16.53 ppm P, 510 ppm K, and 1.41\% of organic matter. The soil of the same station was collected (0-20 cm depth) and used as substrate for pot trial.

The pot trial was conducted in plastic pots $(21 \mathrm{~cm}$ diameter $\times 25 \mathrm{~cm}$ depth) filled with $5 \mathrm{~kg}$ of substrate and placed outdoors. For each pot, ten coated/non-coated seeds were sown on 7 December 2016 thinned to five plants after emergence. Based on germination results, $2 \mathrm{~mL} \mathrm{~kg}^{-1}$ seeds was chosen as concentration for 'Panoramix'. Thus, the experimental layout was a randomized complete block design with three replicates $(n=3)$ that included five seed coating treatments (i.e., Control [distilled water], 'Panoramix' [2 mL $\mathrm{kg}^{-1}$ seeds], 'Spectro', 'Mycoseeds', and 'Panoramix [2 $\mathrm{mL} \mathrm{kg}^{-1}$ seeds] + Spectro') and three durum wheat cultivars. Supplemental irrigation was applied once a week.

For field trial, three blocs $\left(145 \mathrm{~m}^{2}\right)$ subdivided each into 15 plots of $9 \mathrm{~m}^{2}$ (in total 45 plots) containing 6 rows of $6 \mathrm{~m}$ length with $0.2 \mathrm{~m}$ inter-row spacing and $0.5 \mathrm{~m}$ inter-plot spacing. Seeds were hand sown on December 10, 2016 at a rate of 350 seeds per $\mathrm{m}^{2}$. As described for pot trial, the adopted model of the field experiment was the randomized complete block design with three replicates $(n=3)$ per treatment (i.e., five seed coating treatments and three cultivars). Before sowing, a basal fertilization of $100 \mathrm{~kg} \mathrm{ha}^{-1}$ of Di-Ammonium Phosphate (DAP) was applied. Then, a nitrogen (N) fertilization was provided using Ammonium Nitrate (33.5\% N), split into three doses of $100 \mathrm{~kg} \mathrm{ha}^{-1}$ each and applied at 3-leaf (Z13), at tillering (Z26), and at heading (Z32) durum wheat growth stages [69]. Weeds were mechanically controlled using a pre-emergence herbicide, Puma ${ }^{\circledR}$ evolution (fenoxaprop-p-ethyl + iodosulfuron-methyl sodium + mefenpyr-diethyl; Bayer CropScience, Beja, Tunisia) at a rate of $1 \mathrm{~L} \mathrm{ha}^{-1}$ at the 2-3 leaf stage (Z12-13) [69].

\subsection{Effectiveness of Biostimulant Supply Methods under Field Conditions}

In order to identify the most efficient BS supply method, a second field trial was conducted during 2016/17 cropping season at Boulifa experimental station under the same pedoclimatic conditions. Three methods including (i) 'seed coating', (ii) 'foliar spray', and (iii) 'seed coating + foliar spray' were compared to the control (non-treated). Unit bloc was subdivided into 36 plots of $4.5 \mathrm{~m}^{2}(3 \mathrm{~m} \times 1.5 \mathrm{~m})$. Each plot was constituted by 6 rows of $3 \mathrm{~m}$ length, with a $0.2 \mathrm{~m}$ inter-row spacing and a $0.5 \mathrm{~m}$ inter-plot spacing. Durum wheat cultivars were sown on 11 December 2016 and a seeding rate of 350 viable seeds per $\mathrm{m}^{2}$ was adopted. The seeds were coated only with $2 \mathrm{~mL} \mathrm{~kg}^{-1}$ of 'Panoramix', while the foliar spray was applied at the end tillering growth stage (Z29) [69] using $2 \mathrm{~mL} \mathrm{~L}^{-1}$ of 'Panoramix'. The experiment was arranged with a randomized complete block design using three replicates $(n=3)$ per treatment (i.e., three BS application methods and three cultivars). The technical operations (i.e., fertilization, weed control) were performed as described above. 


\subsection{Observations and Measurements}

For germination bioassay, radicle emergence $(>2 \mathrm{~mm})$ was used to determine successful seed germination. The coleoptile $(\mathrm{CL}, \mathrm{cm})$ and radicle length $(\mathrm{RL}, \mathrm{cm})$ were measured after 4 days, while germination rate (GR, \%) was recorded after 7 days.

For pot experiment, three physiological traits were measured, including relative water content, leaf chlorophyll content, and leaf area. At stem elongation stage (Z39) [69], the relative water content ( $\mathrm{RWC}, \%$ ) was determined on five plants per pot and calculated according to Clark and Mac Caig [70] using the following formula:

$$
\operatorname{RWC}(\%)=((\mathrm{FW}-\mathrm{DW}) /(\mathrm{TW}-\mathrm{DW})) \times 100
$$

Variables include FW: fresh weight of harvested leaves; TW: weight of soaked leaves in distilled water for $4 \mathrm{~h}$ at room temperature; DW: weight of dried leaves at $80^{\circ} \mathrm{C}$ for $24 \mathrm{~h}$.

The relative chlorophyll content (Chl, SPAD) of leaves was estimated using a nondestructive dual-wavelength chlorophyll meter (SPAD-502, Minolta, Japan). The 'SPAD value' was determined on flag leaves of five plants per replicate at heading stage (Z59) [69]. The leaf area $\left(\mathrm{LA}, \mathrm{cm}^{2}\right.$ ) was measured also on flag leaves of five plants per pot at Z59 using an electronic planimetre (AM300, Soil Mesures, France).

For pot and field experiments, yield and its related attributes were measured on five plants per pot or per linear meter, including plant height $(\mathrm{PH}, \mathrm{cm})$, biomass $\left(\mathrm{B}\right.$ plant $\left.^{-1}, \mathrm{~g}\right)$, seed number per spike (Seed $\mathrm{N} \mathrm{S}^{-1}$ ), thousand kernel weight (TKW, g), and grain yield (GY plant $\left.{ }^{-1}, \mathrm{~g}\right)$.

To discern the best BS supply method, ten variables were recorded. Chlorophyll content (Chl), plant height $(\mathrm{PH}, \mathrm{cm})$, spikelet number per spike $\left(\mathrm{SpkN} \mathrm{S}{ }^{-1}\right)$, seed number per spike (Seed $\mathrm{N} \mathrm{S}^{-1}$ ), seed weight per spike (Seed $\mathrm{W} \mathrm{S}^{-1}, \mathrm{~g}$ ), and thousand kernel weight (TKW, g) were determined on five plants per $\mathrm{m}^{-2}$. However, biomass $\left(\mathrm{B} \mathrm{m}^{-2}, \mathrm{~g}\right)$, spike number $\left(\mathrm{SN} \mathrm{m}^{-2}\right)$, and grain yield $\left(\mathrm{GY} \mathrm{m}^{-2}, \mathrm{~g}\right)$ were measured for each plot.

\subsection{Statistical Data Analysis}

When data followed a normal distribution, two-way analysis of variance (ANOVA) was used to evaluate the effect of seed coating treatments (or BS application methods), durum wheat cultivars, and their interaction. The resulting variations in data are expressed as the mean \pm standard error $(\mathrm{SE})$ for $n=3$. Duncan's multiple range test at $5 \%$ significance level was employed to compare means of seed coating treatments (or BS application methods) and cultivars. All data were analyzed using SPSS software ver. 16.0 (IBM SPSS Statistics. SPSS for Windows, Version 16.0. SPSS Inc., Chicago, IL, USA, 2007). Otherwise, to describe the relationship between 'treatment-cultivar' combinations, the principal component analysis (PCA) was performed using R statistical software version 4.0 (The R Foundation for Statistical Computing).

\section{Conclusions}

The current study highlighted the BS, 'Panoramix', as an effective and efficient approach in enhancing durum wheat germination using $2 \mathrm{~mL} \mathrm{~kg}^{-1}$ seeds. At this stage, the BS and chemical products acted differently on the above- and below-ground parts of the seedlings; i.e., 'Panoramix' enhanced more the root development and inversely for the chemical treatments. Under semi-arid environment, 'Panoramix' seems to act by modifying physiological processes in plants to stimulate growth and thereby promote yield and its components. In particular, grain yield and biomass were the most enhanced traits. Considering the durum wheat cultivars, 'Salim' showed the best performance using 'Panoramix', but in some cases 'Karim' valorized better than this BS. Overall, 'Panoramix' application by 'seed coating + foliar spray' can be efficiently used to enhance growth. Such results ultimately help farmers to develop more profit-oriented behaviors, which are necessary to increase resilience to environmental stress conditions for sustainable durum wheat production. 
Supplementary Materials: The following are available online at https:/ / www.mdpi.com/article / 10.3390/plants11010133/s1: Table S1-Correlation of the seed germination traits with the first two discriminant axes of PCA. Table S2-Correlation of the physiological and agro-morphological traits obtained under pot conditions with the first two discriminant axes of PCA. Table S3-Correlation of the agro-morphological traits obtained under field conditions with the first two discriminant axes of PCA. Table S4-Correlation of the physiological and agro-morphological traits obtained under field conditions with the first two discriminant axes of PCA. Table S5-Main characteristic of used durum wheat cultivars. Table S6-Mean precipitation $(\mathrm{mm})$ and temperature $\left({ }^{\circ} \mathrm{C}\right)$ in Boulifa/Kef site during 2016/17 cropping season.

Author Contributions: Conceptualization, S.A. and W.H.; methodology, S.A. and W.H.; software, S.A. and I.B.; validation, I.B. and S.A.; formal analysis, S.A. and I.B.; investigation, H.J., S.A. and I.B.; resources, S.A. and W.H.; data curation, S.A. and I.B.; writing-original draft preparation, S.A.; writing-review and editing, I.B. and S.A.; visualization, S.A. and I.B.; supervision, S.A.; project administration, S.A.; funding acquisition, S.A. and W.H. All authors have read and agreed to the published version of the manuscript.

Funding: This research received no external funding.

Institutional Review Board Statement: Not applicable.

Informed Consent Statement: Not applicable.

Data Availability Statement: Available upon reasonable request.

Acknowledgments: This work was financed by the Tunisian Ministry of Higher Education and Scientific Research and the Tunisian Ministry of Agriculture, Hydraulic Resources and Maritime Fishing. We would like to thank Salah Bechrif, Technician at the Experimental Station of Kef/INRAT for his technical support.

Conflicts of Interest: The authors declare no conflict of interest.

\section{Abbreviations}

$\begin{array}{ll}\text { BS } & \text { biostimulant } \\ \text { PGPR } & \text { plant growth-promoting rhizobacteria } \\ \text { PGPF } & \text { plant growth-promoting fungi } \\ \text { AM fungi } & \text { arbuscular mycorrhizal fungi } \\ \text { GR } & \text { germination rate } \\ \text { CL } & \text { coleoptile length } \\ \text { RL } & \text { radicle length } \\ \text { RWC } & \text { relative water content } \\ \text { Chl } & \text { chlorophyll content } \\ \text { LA } & \text { leaf area } \\ \text { PH } & \text { plant height } \\ \text { B } & \text { Biomass } \\ \text { SN } & \text { spike number } \\ \text { SpkN S } & \text { spikelet number per spike } \\ \text { Seed N S } & \text { seed number per spike } \\ \text { Seed W S } & \text { seed weight per spike } \\ \text { TKW } & \text { thousand kernel weight } \\ \text { GY } & \text { grain yield }\end{array}$

\section{References}

1. Hellequin, E.; Monard, C.; Chorin, M.; Le bris, N.; Daburon, V.; Klarzynski, O.; Binet, F. Responses of active soil microorganisms facing to a soil biostimulant input compared to plant legacy effects. Sci. Rep. 2020, 10, 13727. [CrossRef]

2. Yakhin, O.I.; Lubyanov, A.A.; Yakhin, I.A.; Brown, P.H. Biostimulants in plant science: A global perspective. Front. Plant Sci. 2017, 7, 2049. [CrossRef]

3. Du Jardin, P. Plant biostimulants: Definition, concept, main categories and regulation. Sci. Hortic. 2015, 196, 3-14. [CrossRef]

4. Kang, S.M.; Radhakrishnan, R.; Lee, K.E.; You, Y.H.; Ko, J.H.; Kim, J.H.; Lee, I.J. Mechanism of plant growth promotion elicited by Bacillus sp. LKE15 in oriental melon. Acta Agric. Scand. Sect. B Soil Plant Sci. 2015, 65, 637-647. 
5. Haas, D.; Defago, G. Biological control of soil-borne pathogens by fluorescent pseudomonads. Nat. Rev. Microbiol. 2005, 3, 307-319. [CrossRef] [PubMed]

6. $\quad$ Beauregard, P.B.; Chai, Y.; Vlamakis, H.; Losick, R.; Kolter, R. Bacillus subtilis biofilm induction by plant polysaccharides. Proc. Natl. Acad. Sci. USA 2013, 110, E1621-E1630. [CrossRef]

7. Harman, G.E.; Howell, C.R.; Viterbo, A.; Chet, I.; Lorito, M. Trichoderma species-Opportunistic, avirulent plant symbionts. Nat Rev. Microbiol. 2004, 2, 43-56. [CrossRef]

8. Mohiddin, F.A.; Khan, M.R.; Khan, S.M. Why Trichoderma is considered super hero (super fungus) against the evil parasites? Plant Pathol. J. 2010, 9, 92-102. [CrossRef]

9. Poveda, J.; Abril-Urias, P.; Escobar, C. Biological control of plant-parasitic nematodes by filamentous fungi inducers of resistance: Trichoderma, mycorrhizal and endophytic fungi. Front. Microbiol. 2020, 11, 992. [CrossRef]

10. Hermosa, R.; Viterbo, A.; Chet, I.; Monte, E. Plant-beneficial effects of Trichoderma and of its genes. Microbiology 2012, 158, 17-25 [CrossRef]

11. López-Bucio, J.; Pelagio-Flores, R.; Herrera-Estrella, A. Trichoderma as biostimulant: Exploiting the multi level properties of a plant beneficial fungus. Sci. Hortic. 2015, 196, 109-123. [CrossRef]

12. Fiorentino, N.; Ventorino, V.; Woo, S.L.; Pepe, O.; De Rosa, A.; Gioia, L.; Romano, I.; Lombardi, N.; Napolitano, M.; Colla, G.; et al. Trichoderma-based biostimulants modulate rhizosphere microbial populations and improve $\mathrm{N}$ uptake efficiency, yield, and nutritional quality of leafy vegetables. Front. Plant Sci. 2018, 9, 743. [CrossRef]

13. Woo, S.L.; Ruocco, M.; Vinale, F.; Nigro, M.; Marra, R.; Lombardi, N.; Pascale, A.; Lanzuise, S.; Manganiello, G.; Lorito, M. Trichoderma-based products and their widespread use in agriculture. Open Mycol. J. 2014, 8, 71-126. [CrossRef]

14. Smith, F.A.; Smith, S.E. What is the significance of the arbuscular mycorrhizal colonization of many economically important crop plants? Plant Soil 2011, 348, 63-79. [CrossRef]

15. Jiang, Y.; Wang, W.; Xie, Q.; Liu, L.; Wang, D.; Zahang, X.; Yang, C.; Chen, X.; Tang, D.; Wang, E. Plants transfer lipids to sustain colonization by mutualistic mycorrhizal and parasitic fungi. Science 2017, 356, 1172. [CrossRef]

16. Begum, N.; Qin, C.; Ahanger, M.A.; Raza, S.; Khan, M.I.; Ashraf, M.; Ahmed, N.; Zhang, L. Role of arbuscular mycorrhizal fungi in plant growth regulation: Implications in abiotic stress tolerance. Front. Plant Sci. 2019, 10, 1068. [CrossRef]

17. Rocha, I.; Ma, Y.; Souza-Alonso, P.; Vosátka, M.; Freitas, H.; Oliveira, R.S. Seed coating: A tool for delivering beneficial microbes to agricultural crops. Front. Plant Sci. 2019, 10, 1357. [CrossRef]

18. Kaufman, G. Seed coating: A tool for stand establishment; a stimulus to seed quality. HortTechnology 1991, 1, 98-102. [CrossRef]

19. Afzal, I.; Javed, T.; Amirkhani, M.; Taylor, A.G. Modern seed technology: Seed coating delivery systems for enhancing seed and crop performance. Agriculture 2020, 10, 526. [CrossRef]

20. Pedrini, S.; Merritt, D.J.; Stevens, J.; Dixon, K. Seed coating: Science or marketing spin? Trends Plant Sci. 2017, 22, 106-116. [CrossRef] [PubMed]

21. Fernandez, V.; Brown, P.H. From plant surface to plant metabolism: The uncertain fate of foliar-applied nutrients. Front. Plant Sci. 2013, 4, 289. [CrossRef]

22. Díaz-Leguizamón, J.J.; Chingaté-Cruz, O.F.; Sánchez-Reinoso, A.D.; Restrepo-Díaz, H. The effect of foliar applications of a bio-stimulant derived from algae extract on the physiological behavior of lulo seedlings (Solanum quitoense cv. Septentrionale). Cien. Inv. Agr. 2016, 43, 25-37. [CrossRef]

23. Ganugi, P.; Masoni, A.; Pietramellara, G.; Benedettelli, S. A review of studies from the last twenty years on plant-Arbuscular mycorrhizal fungi associations and their uses for wheat crops. Agronomy 2019, 9, 840. [CrossRef]

24. Kumar, A.; Singh, V.K.; Tripathi, V.; Singh, P.P.; Singh, A.K. Plant Growth-Promoting Rhizobacteria (PGPR): Perspective in agriculture under biotic and abiotic Stress. In New and Future Developments in Microbial Biotechnology and Bioengineering: Crop Improvement through Microbial Biotechnology, 1st ed.; Prasad, R., Gill, S.S., Tuteja, N., Eds.; Elsevier: Hoboken, NJ, USA, 2018; pp. 333-342.

25. Rouphael, Y.; Cardarelli, M.; Bonini, P.; Colla, G. Synergistic action of a microbial-based biostimulant and a plant derived-protein hydrolysate enhances lettuce tolerance to alkalinity and salinity. Front. Plant Sci. 2017, 8, 131. [CrossRef] [PubMed]

26. Zin, N.A.; Badaluddin, N.A. Biological functions of Trichoderma spp. for agriculture applications. Ann. Agric. Sci. 2020, 65, 168-178. [CrossRef]

27. Saa, S.; Olivos-Del Rio, A.; Castro, S.; Brown, P.H. Foliar application of microbial and plant based biostimulants increases growth and potassium uptake in almond (Prunus dulcis [Mill.] D. A. Webb). Front. Plant Sci. 2015, 6, 1-9. [CrossRef]

28. Sabir, A.; Yazar, K.; Sabir, F.; Kara, Z.; Yazici, M.A.; Goksu, N. Vine growth, yield, berry quality attributes and leaf nutrient content of grapevines as influenced by seaweed extract (Ascophyllum nodosum) and nanosize fertilizer pulverizations. Sci. Hortic. 2014, 175, 1-8. [CrossRef]

29. Sadok, W.; Schoppach, R.; Ghanem, M.E.; Zucca, C.; Sinclair, T.R. Wheat drought-tolerance to enhance food security in Tunisia, birthplace of the Arab Spring. Eur. J. Agron. 2019, 107, 1-9. [CrossRef]

30. Chahed, Y. Tunisia Grain, Grain and Feed Annual; Grain Report; USDA Foreign Agriculture Service: Washington, DC, USA, 2009.

31. Kthiri, Z.; Ben Jabeur, M.; Machraoui, M.; Gargouri, S.; Hiba, K.; Hamada, W. Coating seeds with Trichoderma strains promotes plant growth and enhance the systemic resistance against Fusarium crown rot in durum wheat. Egypt. J. Biol. Pest Control 2020, 30, 139. [CrossRef] 
32. Harman, G.E. Myths and dogmas of biocontrol changes in perceptions derived from research on Trichoderma harzinum T-22. Plant Dis. 2000, 84, 377-393. [CrossRef] [PubMed]

33. Poštić, D.; Štrbanović, R.; Tabaković, M.; Popović, T.; Cirić, A.; Banjac, N.; Trkulja, N.; Stanisavljević, R. Germination and the initial seedling growth of lettuce, celeriac and wheat cultivars after micronutrient and a biological application pre-sowing seed treatment. Plants 2021, 10, 1913. [CrossRef] [PubMed]

34. Li, Y.-J.; Hu, Q.-P. Studying of the promotion mechanism of Bacillus subtilis QM3 on wheat seed germination based on $\beta$-amylase. Open Life Sci. 2020, 15, 553-560. [CrossRef] [PubMed]

35. Hu, Q.P.; Liu, R.X.; Liu, J.X. Effects of Bacillus subtilis QM3 on germination and antioxidant enzymes activities of wheat seeds under salt stress. Open Access Libr. 2019, 6, e5218. [CrossRef]

36. Alvarado-Sanabria, O.H.; Álvarez-Herrera, J.G. Effect of indole-3-butyric acid and Trichoderma harzianum Rifai on asexual cape gooseberry propagation (Physalis peruviana L.). Agron. Colomb. 2014, 32, 326-333. [CrossRef]

37. Siemering, G.; Ruark, M.; Geven, A. The value of Trichoderma for Crop Production; University of Wisconsin-Extension, Cooperative Extension: Madison, WI, USA, 2016.

38. Bader, A.N.; Salerno, G.L.; Covacevich, F.; Consolo, V.F. Native Trichoderma harzianum strains from Argentina produce indole-3 acetic acid and phosphorus solubilization, promote growth and control wilt disease on tomato (Solanum lycopersicum L.). J. King Saud. Univ. Sci. 2020, 32, 867-873. [CrossRef]

39. Cai, F.; Yu, G.; Wang, P.; Wei, Z.; Fu, L.; Shen, Q.; Chen, W. Harzianolide, a novel plant growth regulator and systemic resistance elicitor from Trichoderma harzianum. Plant Physiol. Biochem. 2013, 73, 106-113. [CrossRef]

40. Vinale, F.; Nigro, M.; Sivasithamparam, K.; Flematti, G.; Ghisalberti, E.; Ruocco, M.; Varlese, R.; Marra, R.; Lanzuise, S.; Eid, A.; et al. Harzianic acid: A novel siderophore from Trichoderma harzianum. FEMS Microbiol. Lett. 2013, 347, 123-129. [CrossRef]

41. Radhakrishnan, R.; Hashem, A.; Abdallah, E.F. Bacillus: A biological tool for crop improvement through bio-molecular changes in adverse environments. Front. Physiol. 2017, 8, 667. [CrossRef]

42. Ahmed, A.; Hasnain, S. Auxin-producing Bacillus sp.: Auxin quantification and effect on the growth of Solanum tuberosum. Pure Appl. Chem. 2010, 82, 313-319. [CrossRef]

43. Arkhipova, T.N.; Veselov, S.U.; Melentiev, A.I.; Martynenko, E.V.; Kudoyarova, G.R. Ability of bacterium Bacillus subtilis to produce cytokinins and to influence the growth and endogenous hormone content of lettuce plants. Plant Soil 2005, 272, 201-209. [CrossRef]

44. Pourbabaee, A.A.; Bahmani, E.; Alikhani, H.A.; Emami, S. Promotion of wheat growth under salt stress by halotolerant bacteria containing ACC deaminase. J. Agric. Sci. Technol. 2016, 18, 855-864.

45. Radhakrishnan, R.; Lee, I.J. Gibberellins producing Bacillus methylotrophicus KE2 supports plant growth and enhances nutritional metabolites and food values of lettuce. Plant Physiol. Biochem. 2016, 109, 181-189. [CrossRef]

46. Jha, C.K.; Saraf, M. Plant Growth Promoting Rhizobacteria (PGPR): A review. E3 J. Agric. Res. Dev. 2015, 5, $0108-0119$.

47. Vacheron, J.; Desbrosses, G.; Bouffaud, M.; Touraine, B.; Moenne-Loccoz, Y.; Muller, D.; Legendre, L.; Wisniewski-Dye, F.; Prigent-Combaret, C. Plant Growth-Promoting Rhizobacteria and root system functioning. Front. Plant Sci. $2013,4,356$. [CrossRef]

48. Xu, M.; Sheng, J.; Chen, L.; Men, Y.; Gan, L.; Guo, S.; Shen, L. Bacterial community compositions of tomato (Lycopersicum esculentum Mill.) seeds and plant growth promoting activity of ACC deaminase producing Bacillus subtilis (HYT-12-1) on tomato seedlings. World J. Microbiol. Biotechnol. 2014, 30, 835-845. [CrossRef] [PubMed]

49. Kuan, K.B.; Othman, R.; Rahim, K.A.; Shamsuddin, Z.H. Plant Growth-Promoting Rhizobacteria inoculation to enhance vegetative growth, nitrogen fixation and nitrogen remobilisation of maize under greenhouse conditions. PLoS ONE 2016, 11, e0152478. [CrossRef] [PubMed]

50. Piotrowska, M.; Kusewicz, D. Soil microflora. In Technical Microbiology; Microorganisms and Their Environment; Libudzisz, Z., Kowal, K., Eds.; Scientific Publisher PWN: Warszawa, Poland, 2007; pp. 195-200.

51. Ding, Y.; Wang, J.; Liu, Y.; Chen, S. Isolation and identification of nitrogen-fixing bacilli from plant rhizospheres in Beijing region. J. Appl. Microbiol. 2005, 99, 1271-1281. [CrossRef]

52. Kang, S.M.; Radhakrishnan, R.; You, Y.H.; Joo, G.J.; Lee, I.J.; Lee, K.E.; Kim, J.H. Phosphate solubilizing Bacillus megaterium mj1212 regulates endogenous plant carbohydrates and amino acids contents to promote mustard plant growth. Indian J. Microbiol. 2014, 54, 427-433. [CrossRef]

53. Nadeem, S.M.; Shaharoona, B.; Arshad, M.; Crowley, D.E. Population density and functional diversity of plant growth promoting rhizobacteria associated with avocado trees in saline soils. Agric. Ecosyst. Environ. Appl. Soil Ecol. 2012, 62, 147-154. [CrossRef]

54. Huang, X.F.; Jacqueline, M.; Chaparro, K.F.; Zhang, R.; Shen, Q.; Vivanco, J.M. Rhizosphere interactions: Root exudates, microbes, and microbial communities. Botany 2014, 92, 267-275. [CrossRef]

55. Sood, M.; Kapoor, D.; Kumar, V.; Sheteiwy, M.S.; Ramakrishnan, M.; Landi, M.; Araniti, F.; Sharma, A. Trichoderma: The "secrets" of a multitalented biocontrol agent. Plants 2020, 9, 762. [CrossRef]

56. Carvalhais, L.C.; Dennis, P.G.; Badri, D.V.; Kidd, B.N.; Vivanco, J.M.; Schenk, P.M. Linking jasmonic acid signaling, root exudates, and rhizosphere microbiomes. Mol. Plant-Microbe Interact. 2015, 28, 1049-1058. [CrossRef]

57. Al-Karaki, G.N.; Al-Raddad, A.; Clark, R.B. Water stress and mycorrhizal isolate effects on growth and nutrient acquisition of wheat. J. Plant Nutr. 1998, 21, 891-902. [CrossRef] 
58. Zhang, S.; Lehmann, A.; Zheng, W.; You, Z.; Rillig, M.C. Arbuscular mycorrhizal fungi increase grain yields: A meta-analysis. New Phytol. 2019, 222, 543-555. [CrossRef]

59. Davies, F.T., Jr.; Potter, J.R.; Linderman, R.G. Mycorrhiza and repeated drought exposure affect drought resistance and extraradical hyphae development on pepper plants independent of plant size and nutrient content. J. Plant Physiol. 1992, 139, 289-294. [CrossRef]

60. Jayne, B.; Quigley, M. Influence of arbuscular mycorrhiza on growth and reproductive response of plants under water deficit: A meta analysis. Mycorrhiza 2014, 24, 109-119. [CrossRef]

61. Adesemoye, A.; Torbert, H.; Kloepper, J. Plant Growth-Promoting Rhizobacteria allow reduced application rates of chemical fertilizers. Microb. Ecol. 2009, 58, 921-929. [CrossRef]

62. Norrie, J.; Keathley, J.P. Benefits of Ascophyllum nodosum marine plant extract applications to 'Thompson seedless' grape production. Acta Hortic. 2006, 71, 22-28. [CrossRef]

63. Gajc-Wolska, J.; Spizewski, T.; Grabowska, A. The effect of seaweed extracts on the yield and quality parameters of Broccoli (Brassica oleracea var. cymosa L.) in open field production. Acta Hortic. 2013, 1009, 83-89. [CrossRef]

64. Sharma, H.S.S.; Fleming, C.; Selby, C.; Rao, J.R.; Martin, T. Plant biostimulants: A review on the processing of macroalgae and use of extracts for crop management to reduce abiotic and biotic stresses. J. Appl. Phycol. 2014, 26, 465-490. [CrossRef]

65. Amutha, M. Establishment of Beauveria bassiana (Balsamo) vuillemin as an endophyte in cotton. Int. J. Curr. Microbiol. App. Sci. 2017, 6, 2506-2513. [CrossRef]

66. Tavares, L.C.; Rufino, C.D.A.; Brunes, A.P.; Friedrich, F.F.; Barros, A.C.S.A.; Villela, F.A. Physiological performance of wheat seeds coated with micronutrients. J. Seed Sci. 2013, 35, 28-34. [CrossRef]

67. Xue, A.G.; Guo, W.; Chen, Y.; Siddiqui, I.; Marchand, G.; Liu, J.; Ren, C. Effect of seed treatment with novel strains of Trichoderma spp. on establishment and yield of spring wheat. J. Crop Prot. 2017, 96, 97-102. [CrossRef]

68. USDA. Soil Classification: A Comprehensives System (Prepared by) Soil Survey Staff; Government Printing Office: Washington, DC, USA, 2013.

69. Zadoks, J.C.; Chang, T.T.; Konzak, C.F. A decimal code for the growth stages of cereals. Weed Res. 1974, 14, 415-421. [CrossRef]

70. Clark, J.M.; Mac-Caig, T.N. Excised leaf water relation capability as an indicator of drought resistance of Triticum genotypes. Can. J. Plant Sci. 1982, 62, 571-576. [CrossRef] 